\title{
Ferrocenyl-substituted allenylidene complexes of chromium, molybdenum and tungsten: Synthesis, structure and reactivity
}

\author{
Thomas Haas, Stefan Oswald, Andrea Niederwieser, Benno Bildstein, Florian Kessler, \\ Helmut Fischer
}

Dedicated to Professor Bernhard Lippert

\begin{abstract}
Bis(ferrocenyl) substituted allenylidene complexes, $\left[(\mathrm{CO})_{5} \mathrm{M} \quad \mathrm{C} \quad \mathrm{C} \quad \mathrm{CFc}_{2}\right]\left(\mathbf{1 a} \mathbf{c}, \mathrm{Fc}=\left(\mathrm{C}_{5} \mathrm{H}_{4}\right) \mathrm{Fe}\left(\mathrm{C}_{5} \mathrm{H}_{5}\right), \mathrm{M}=\mathrm{Cr}(\mathbf{a}), \mathrm{Mo}(\mathbf{b}), \mathrm{W}(\mathbf{c})\right)$ were obtained by sequential reaction of $\mathrm{Fc}_{2} \mathrm{C} \mathrm{O}$ with $\mathrm{Me}_{3} \mathrm{Si} \mathrm{C} \mathrm{CH}, \mathrm{KF} / \mathrm{MeOH}, n$ BuLi, and $\left[(\mathrm{CO})_{5} \mathrm{M}(\mathrm{THF})\right]$. For the synthesis of related mono(ferrocenyl)allenylidene chromium complexes, $\left[(\mathrm{CO})_{5} \mathrm{Cr} \quad \mathrm{C} C \mathrm{C}(\mathrm{Fc}) \mathrm{R}\right]\left(\mathrm{R}=\mathrm{Ph}\right.$, $\left.\mathrm{NMe}_{2}\right)$, three different routes were developed: (a) reaction of the deprotonated propargylic alcohol $\mathrm{HC} \quad \mathrm{CC}(\mathrm{Fc})(\mathrm{Ph}) \mathrm{OH}$ with $\left[(\mathrm{CO})_{5} \mathrm{Cr}(\mathrm{THF})\right]$ followed by desoxygenation with $\mathrm{Cl}_{2} \mathrm{C} \quad \mathrm{O}$, (b) Lewis acid induced alcohol elimination from alkenyl(alkoxy)carbene complexes, $\left[(\mathrm{CO})_{5} \mathrm{Cr} \mathrm{C}(\mathrm{OR}) \mathrm{CH} \mathrm{C}(\mathrm{NMe})_{2} \mathrm{Fc}\right]$, and (c) replacement of $\mathrm{OMe}$ in $\left[(\mathrm{CO})_{5} \mathrm{Cr} \quad \mathrm{C} \quad \mathrm{C} \quad \mathrm{C}(\mathrm{OMe}) \mathrm{NMe}_{2}\right]$ by Fc. Complex 1a was also formed when the mono(ferrocenyl)alleny lidene complex $\left[(\mathrm{CO})_{5} \mathrm{Cr} \quad \mathrm{C} \quad \mathrm{C} \quad \mathrm{C}(\mathrm{Fc}) \mathrm{NMe}_{2}\right]$ was treated first with $\mathrm{Li}[\mathrm{Fc}]$ and the resulting adduct then with $\mathrm{SiO}_{2}$. The replacement route (c) was also applied to the synthesis of an allenylidene complex (7a) with a $\mathrm{C} \quad \mathrm{C}$ spacer in between the ferrocenyl unit and $\mathrm{C}_{\gamma}$ of the allenylidene ligand, $\left[(\mathrm{CO})_{5} \mathrm{Cr} \quad \mathrm{C} \quad \mathrm{C} \quad \mathrm{C}\left(\mathrm{NMe}_{2}\right) \mathrm{C} \quad \mathrm{CFc}\right]$. The related complex containing a $\mathrm{CH} \quad \mathrm{CH}$ spacer $(\mathbf{9 a})$ was prepared by condensation of $\left[(\mathrm{CO})_{5} \mathrm{Cr} \quad \mathrm{C} \quad \mathrm{C} \quad \mathrm{C}(\mathrm{Me}) \mathrm{NMe}_{2}\right]$ with formylferrocene in the presence of $\mathrm{NEt}_{3}$. The bis(ferrocenyl) substituted alleny lidene complexes 1a c added $\mathrm{HNMe}_{2}$ across the $\mathrm{C}_{\alpha} \mathrm{C}_{\beta}$ bond to give alkenyl(dimethylamino)carbene complexes and reacted with diethylaminopropyne by regioselective insertion of the $\mathrm{C} C$ bond into the $\mathrm{C}_{\beta} \mathrm{C}_{\gamma}$ bond to afford alkenyl(diethylamino)allenylidene complexes, $\left[(\mathrm{CO})_{5} \mathrm{M} \quad \mathrm{C} \quad \mathrm{C} \quad \mathrm{C}\left(\mathrm{NEt}_{2}\right) \mathrm{CMe} \mathrm{CFc}_{2}\right]$. The structures of 5a, 7a, and 9a were established by $\mathrm{X}$ ray diffraction studies.
\end{abstract}

\section{Introduction}

The carbon chain in allenylidene complexes, $\left[\mathrm{L}_{n} \mathrm{M}=\mathrm{C}=\mathrm{C}=\mathrm{C}\left(\mathrm{R}^{1}\right) \mathrm{R}^{2}\right][1]$ should be able to efficiently mediate electronic communication between the terminal groups. Recently [2], we demonstrated that the ferrocenyl

\footnotetext{
${ }^{*}$ Corresponding author. Tel.: +49 7531 882783; fax: +49 7531883136 . E mail address: helmut.fischer@uni konstanz.de (H. Fischer).
}

and the pentacarbonyl group in complexes of the type A (n 0,1$)$ strongly interact. Oxidation of the ferrocenyl unit led to a strong shift of the $v(\mathrm{CO})$ vibrations to higher energy. In these complexes the ferrocenyl group was connected with the allenylidene group via $\mathrm{CC}\left(\mathrm{C}_{6} \mathrm{H}_{4} \mathrm{CC}\right)_{n}$ spacers and the terminal carbon atom of the allenylidene $\mathrm{C}_{3}$ fragment was incorporated into a $N$-ethyl pyridine ring acting as $\pi$-donor. We were now interested in allenylidene complexes with ferrocenyl units directly attached to the terminal carbon atom (C3) of the allenylidene ligand. 


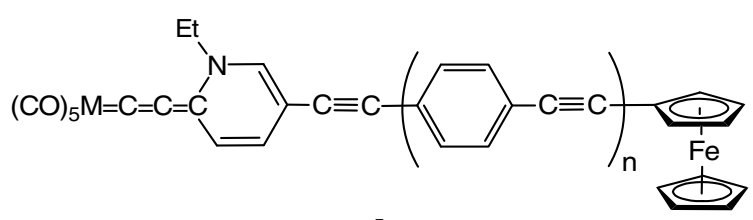

A

Several routes leading to allenylidene complexes have been developed in recent years [1]. Broadly applicable, among others, are (a) elimination of water or an alcohol from suitable carbene precursors or vinylidene precursors (usually obtained from substituted propargylic alcohols) [3], (b) reactions of dilithiated substituted 2-propyn-1-ols, $\left[\mathrm{LiC} \equiv \mathrm{CCR}_{2}(\mathrm{OLi})\right]$, with metal carbonyls (usually $\left[\mathrm{M}(\mathrm{CO})_{6}\right]$ or $\left.\left[\mathrm{M}(\mathrm{CO})_{5}(\mathrm{THF})\right]\right)$ and subsequent loss of oxo or alkoxy groups [4], (c) elimination of $\mathrm{X}^{-}$from alkynyl metallates, $\left[\mathrm{L}_{n} \mathrm{M} \mathrm{C} \equiv \mathrm{C} \mathrm{CR}_{2} \mathrm{X}\right]^{-}[5]$ or $X$-alkylation of alkynyl metallates, $\left[\mathrm{L}_{n} \mathrm{M} \mathrm{C} \equiv \mathrm{C} \mathrm{C}(=\mathrm{X}) \mathrm{R}\right]^{-}[6]$, and (d) the modification of already existing allenylidene ligands via substitution processes [7].

We now report on various synthetic approaches to (a) mono(ferrocenyl)- and bis(ferrocenyl)allenylidene complexes of chromium, molybdenum and tungsten and (b) complexes in which the ferrocenyl unit is separated from the allenylidene spine by an unsaturated spacer.

\section{Results and discussion}

The most promising method for the synthesis of bis(ferrocenyl)-substituted allenylidene complexes seemed to be the route successfully employed for bis(aryl)-substituted allenylidene pentacarbonyl complexes [4b].

Double deprotonation of 1,1-bis(ferrocenyl)propargylic alcohol (obtained by sequential reaction of bis(ferrocenyl)ketone with deprotonated trimethylsilylacetylene at $\left.-80^{\circ} \mathrm{C}\right)$ and reaction with $\left[(\mathrm{CO})_{5} \mathrm{Cr}(\mathrm{THF})\right]$ at room temperature in THF followed by desoxygenation of the resulting alkynyl chromate with phosgene in toluene $\mathrm{CH}_{2} \mathrm{Cl}_{2}$ at $-100{ }^{\circ} \mathrm{C}$ gave the bis(ferrocenyl)allenylidene chromium complex 1a (Scheme 1). Chromatographic workup of the reaction mixture finally afforded $\mathbf{1 a}$ in $39 \%$ yield.

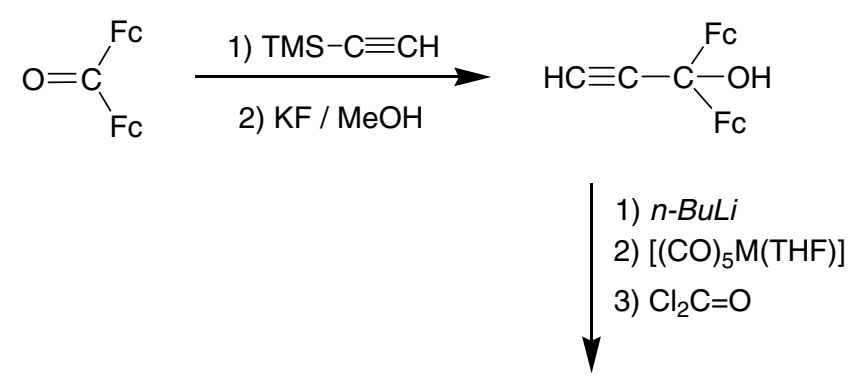

$\mathrm{M}=\mathrm{Cr}(\mathbf{a}), \mathrm{Mo}(\mathbf{b}), \mathrm{W}(\mathbf{c})$;

$\mathrm{Fc}=\mathrm{C}_{5} \mathrm{H}_{4} \mathrm{FeC}_{5} \mathrm{H}_{5}$

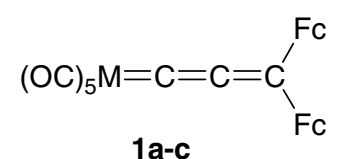

The molybdenum and tungsten complexes $\mathbf{1 b}$ and $\mathbf{1 c}$ were obtained when $\left[(\mathrm{CO})_{5} \mathrm{Mo}(\mathrm{THF})\right]$ and $\left[(\mathrm{CO})_{5} \mathrm{~W}(\mathrm{THF})\right]$ were employed instead of $\left[(\mathrm{CO})_{5} \mathrm{Cr}(\mathrm{THF})\right]$. Whereas the chromium complex 1a turned out to be stable at room temperature, the molybdenum and tungsten allenylidene complexes 1b and 1c proved to be unstable and quickly decomposed at temperature above $-40{ }^{\circ} \mathrm{C}$.

The corresponding reaction of 1-ferrocenyl-1-phenylprop-2-in-1-ol with $\left[(\mathrm{CO})_{5} \mathrm{Cr}(\mathrm{THF})\right]$ and subsequent desoxygenation of the resulting chromate yielded the monoferrocenylallenylidene complex 2a (Scheme 2). The desoxygenation step could be simplified by substituting basic alumina for phosgene. Alumina is much easier to handle and can simultaneously be used as the stationary phase in the chromatographic purification step.

Analogously to $\mathbf{1 b}$ and $\mathbf{1 c}$, complex $\mathbf{2 a}$ proved to be unstable and rapidly decomposed above $-40{ }^{\circ} \mathrm{C}$. Therefore, its formation like that of $\mathbf{1 b}$, $\mathbf{c}$ was established by spectroscopic means only.

From our earlier studies it followed that $\pi$-donor substituents at $\mathrm{C}_{\gamma}$ of the allenylidene ligand considerably stabilize these allenylidene pentacarbonyl complexes. Therefore, displacing the phenyl substituent by an amino group was expected to lead to stable complexes. However, the routes shown in Schemes 1, 2 could not be adapted to the synthesis of amino(ferrocenyl)allenylidene complexes and therefore another pathway had to be developed. The most feasible one was a modification of the route originally developed by Fischer et al. for the synthesis of the first allenylidene chromium complex [3a].

Addition of dimethylamine across the triple bond of the alkoxy(alkynyl)carbene complexes $\left[(\mathrm{CO})_{5} \mathrm{Cr}=\mathrm{C}(\mathrm{OEt})\right.$ $\mathrm{C} \equiv \mathrm{C} \mathrm{Fc}]\left(\right.$ 3a) $[8]$ gave $\left[(\mathrm{CO})_{5} \mathrm{Cr}=\mathrm{C}(\mathrm{OEt}) \mathrm{CH}=\mathrm{C}\left(\mathrm{NMe}_{2}\right)\right.$ $\mathrm{Fc}$ (4a). Subsequent alcohol elimination induced by $\mathrm{BCl}_{3}$ yielded the amino(ferrocenyl)allenylidene complexes 5a (Scheme 3).

An alternative pathway likewise leading to $\mathbf{5 a}$ involved replacing the methoxy substituent in 6a by the ferrocenyl unit. Already earlier we were able to demonstrate that the alkoxy group at $\mathrm{C}_{\gamma}$ in alkoxyallenylidene pentacarbonyl complexes is exchangeable $[1 b, 6,7]$.

When at room temperature 1.5 equiv. of ferrocenyl lithium was added to a solution of $\mathbf{6 a}$ in THF, complex $\mathbf{5 a}$ quickly formed. Addition of silica led to completion of the substitution process (Scheme 4).

Addition of equimolar amounts of lithiated cymanthrene, $\mathrm{Li}\left[(\mathrm{CO})_{3} \mathrm{MnC}_{5} \mathrm{H}_{4}\right]$, or lithiated tricarbonyl(benzene)chromium, $\mathrm{Li}\left[(\mathrm{CO})_{3} \mathrm{CrC}_{6} \mathrm{H}_{5}\right]$, instead of $\mathrm{Li}\left[\left(\mathrm{C}_{5} \mathrm{H}_{4}\right)\right.$ $\mathrm{Fe}\left(\mathrm{C}_{5} \mathrm{H}_{5}\right)$ ] gave unstable compounds that decomposed rapidly even at low temperatures.

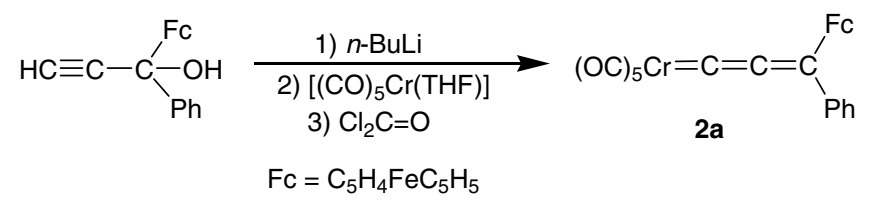


<smiles>CCOC(C#CCF)=C(O)OC</smiles><smiles>CCOC(=O)C=C(C=C(C)F)OCC</smiles>

$\mathrm{FC}=\mathrm{C}_{5} \mathrm{H}_{4} \mathrm{FeC}_{5} \mathrm{H}_{5}$

Scheme 3.

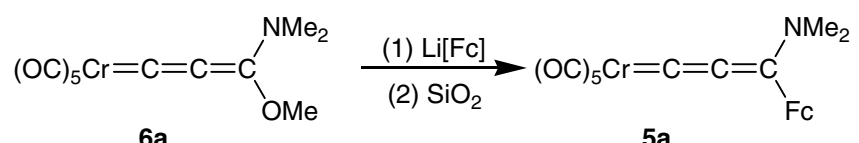

Scheme 4.

The amino substituent in $\mathbf{5 a}$ could likewise be replaced by the ferrocenyl group. Treating solutions of $\mathbf{5 a}$ with an excess of $\mathrm{Li}[\mathrm{Fc}]$ gave rise to the formation of the bis(ferrocenyl)allenylidene complex 1a. However, the rate for substitution of $\mathrm{Fc}$ for $\mathrm{NMe}_{2}$ in $\mathbf{5 a}$ is considerably less (by a factor of at least 10) than for OMe in $\mathbf{6 a}$. When solutions of $\mathbf{6 a}$ in THF were treated with 5 equiv. of $\mathrm{Li}[\mathrm{Fc}]$ for several hours, compound 1a was the final product (Scheme 5) very likely formed via $\mathbf{5 a}$ as intermediate.

A $\mathrm{C} \equiv \mathrm{C}$ spacer between $\mathrm{C}_{\gamma}$ of the allenylidene ligand and the ferrocenyl unit could be introduced by using lithium ethynylferrocene instead of $\mathrm{Li}[\mathrm{Fc}]$ in the reaction with 6a. The resulting complex 7a (Scheme 6) obtained in $52 \%$ yield was characterized by IR, NMR, and UV Vis spec-

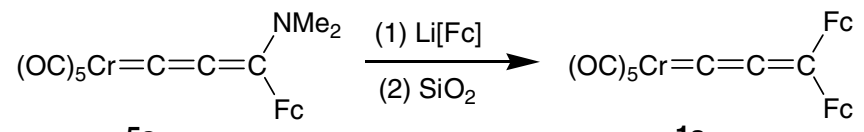

$5 a$

$1 a$

Scheme 5 . troscopy. The structure of $7 \mathbf{a}$ was additionally established by an X-ray diffraction study (see below).

However, a $\mathrm{CH}=\mathrm{CH}$ spacer could not be introduced by the same methodology. Instead, a new route had to be developed. Already earlier [9] we observed that the hydrogen atoms of the $\mathrm{C}_{\gamma}$-methyl substituent in $\left[(\mathrm{CO})_{5} \mathrm{Cr}=\mathrm{C}=\right.$ $\left.\mathrm{C}=\mathrm{C}\left(\mathrm{NMe}_{2}\right) \mathrm{Me}\right](\mathbf{8 a})$ are acidic similar to the $\alpha-\mathrm{CH}$ atoms in methylcarbene complexes $\left[(\mathrm{CO})_{5} \mathrm{M}=\mathrm{C}(\mathrm{XR}) \mathrm{Me}\right](\mathrm{M}$ $\mathrm{Cr}, \mathrm{W}$; XR OMe, NHMe) [10]. Condensation of formylferrocene with $\mathbf{8 a}$ in the presence of a tertiary amine offered a feasible route to an insertion of a $\mathrm{CH}=\mathrm{CH}$ unit in between $\mathrm{C}_{\gamma}$ and the ferrocene unit and thus an extension of the unsaturated chain in 5a. By this method the dimethylamino(trans-ferrocenylethenyl)allenylidene complex 9a (Scheme 7) was obtained from 5a, after chromatography and recrystallization, in $41 \%$ yield. Complex 9a was characterized by spectroscopic means and by an X-ray structural analysis.

The reactivity of the new bis(ferrocenyl)allenylidene complexes 1a c towards $C$ - and $N$-nucleophiles was briefly investigated. Complexes 1a c add dimethylamine across the $\mathrm{C}_{\alpha} \mathrm{C}_{\beta}$ bond of the allenylidene ligand to form alkenyl(dimethylamino)carbene complexes 10a c (Scheme 8).

A similar $C_{\alpha} C_{\beta}$ addition was observed in the reactions of diethylamine with diarylallenylidene complexes $\left[(\mathrm{CO})_{5} \mathrm{M}=\mathrm{C}=\mathrm{C}=\mathrm{C}(\operatorname{Aryl})_{2}\right] \quad(\mathrm{M} \quad \mathrm{Cr}, \mathrm{W}) \quad[11]$ and of dimethylamine with $\left[(\mathrm{CO})_{5} \mathrm{Cr}=\mathrm{C}=\mathrm{C}=\mathrm{C}\left(\mathrm{NR}_{2}\right) \mathrm{Ph}\right] \quad(\mathrm{R}$

Et. $i$-Pr) [12]. In contrast, $\left[(\mathrm{CO})_{5} \mathrm{Cr}=\mathrm{C}=\mathrm{C}=\mathrm{C}\left(\mathrm{NMe}_{2}\right) \mathrm{Ph}\right]$ [7a] reacts with primary amines by substitution of $\mathrm{N}(\mathrm{H}) \mathrm{R}$ for $\mathrm{NMe}_{2}$ and primary and secondary amines displace the methoxy group in $\left[(\mathrm{CO})_{5} \mathrm{M}=\mathrm{C}=\mathrm{C}=\mathrm{C}(\mathrm{OMe}) \mathrm{Ph}\right]$ $[7 \mathrm{~b}, 13]$.

The reaction of 1a $\mathbf{c}$ with diethylaminopropyne proceeds by formal insertion of the $\mathrm{C} \equiv \mathrm{C}$ triple bond into the $\mathrm{C}_{\beta} \mathrm{C}_{\gamma}$ bond of the allenylidene ligand. The reaction is presumably initiated by nucleophilic attack of the $C(\mathrm{Me})$ atom of the ynamine at $\mathrm{C}_{\gamma}$ of 1a c. Subsequent cyclization of the resulting zwitterionic species followed by cycloreversion then gives 11a c (Scheme 9).

In contrast, from the corresponding reaction of diarylallenylidene complexes with diethylaminopropyne [14], mixtures of alkenyl(aryl)allenylidene complexes (comparable to 11a c) and cyclobutenylidene complexes (formed by cycloaddition of the $\mathrm{C} \equiv \mathrm{C}$ triple bond to the $\mathrm{C}_{\alpha} \mathrm{C}_{\beta}$ bond

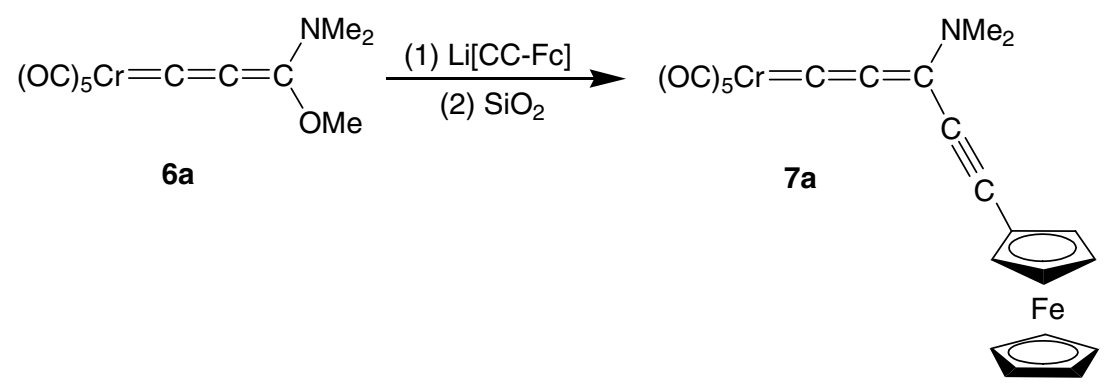




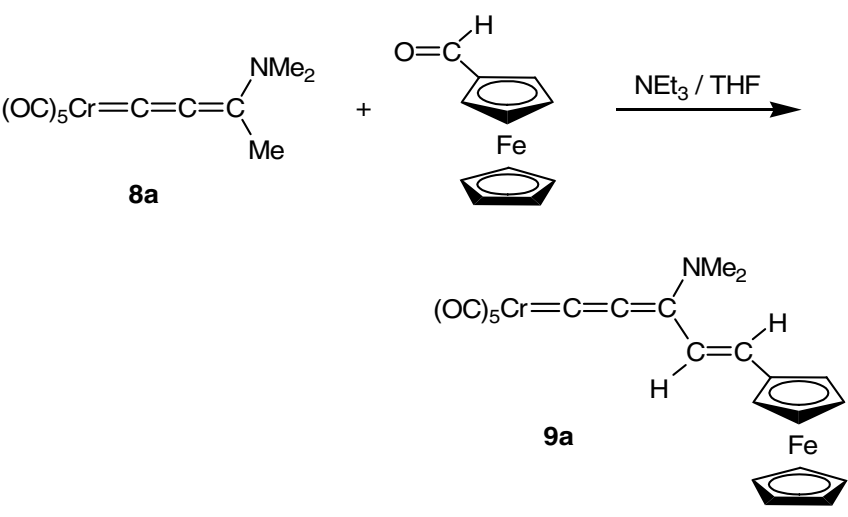

Scheme 7.

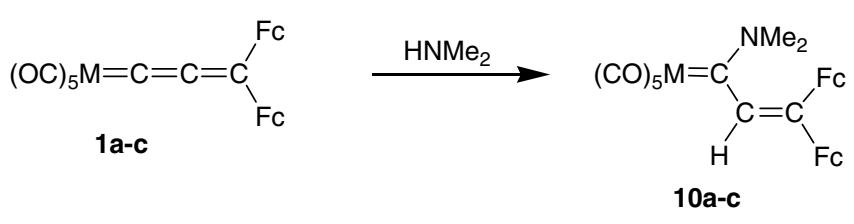

$\mathrm{M}=\mathrm{Cr}(\mathbf{a}), \mathrm{Mo}(\mathbf{b}), \mathrm{W}(\mathbf{c}) ; \quad \mathrm{Fc}=\mathrm{C}_{5} \mathrm{H}_{4} \mathrm{FeC}_{5} \mathrm{H}_{5}$

Scheme 8 .

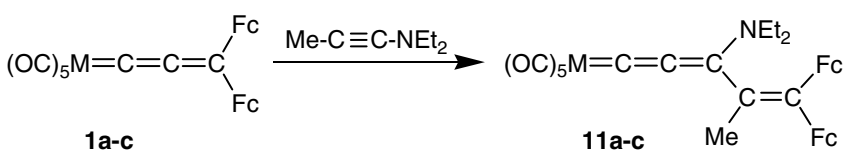

$\mathrm{M}=\mathrm{Cr}(\mathbf{a}), \mathrm{Mo}(\mathbf{b}), \mathrm{W}(\mathbf{c}) ; \quad \mathrm{Fc}=\mathrm{C}_{5} \mathrm{H}_{4} \mathrm{FeC}_{5} \mathrm{H}_{5}$

Scheme 9.

without subsequent cycloreversion) are obtained. The product ratios strongly depend on the solvent and the substitution pattern at $\mathrm{C}_{\gamma}$. Increasing the donor capacity of the substituents at $\mathrm{C}_{\gamma}$ shifts the product ratio towards the insertion product. When bis(4-dimethylaminophenyl)allenylidene complexes are employed, the ratio insertion/addition product is $12.4(\mathrm{Cr})$ and $15.0(\mathrm{~W})$. The failure to observe the formation of cyclobutenylidene complexes in the reaction of $\mathbf{1 a} \mathbf{c}$ with diethylaminopropyne indicates that the ferrocenyl unit acts as a better donor than the 4-dimethylaminophenyl substituent.

The new complexes were characterized by spectroscopic means. The structures of $\mathbf{5 a}, 7 \mathbf{a}$, and $9 \mathbf{a}$ were additionally established by X-ray structure analyses (Figs 1 3, Tables 1 and 3). Unfortunately, the crystals of $\mathbf{5 a}$ were of rather poor quality leading to large standard deviations. However, the bond distances and angles measured are in accord with those of 7a and 9a. All three structures show some common features. The allenylidene plane (formed by $\mathrm{C}_{\gamma}$ and the three atoms bonded to $\mathrm{C}_{\gamma}$, sum of angles at $\mathrm{C}_{\gamma}$ : $360^{\circ}$ ) is staggered with respect to the cis-CO ligands. The $\mathrm{C}_{5} \mathrm{H}_{4}$ plane of 7a and 9a only marginally deviates from coplanarity with the allenylidene plane (angle between both planes: $1.7^{\circ}(\mathbf{7 a}), 2.2^{\circ}(\mathbf{9 a})$ and $\left.12.1^{\circ}(\mathbf{5 a})\right)$. The significantly larger deviation in $\mathbf{5 a}$ is presumably due to steric influences.

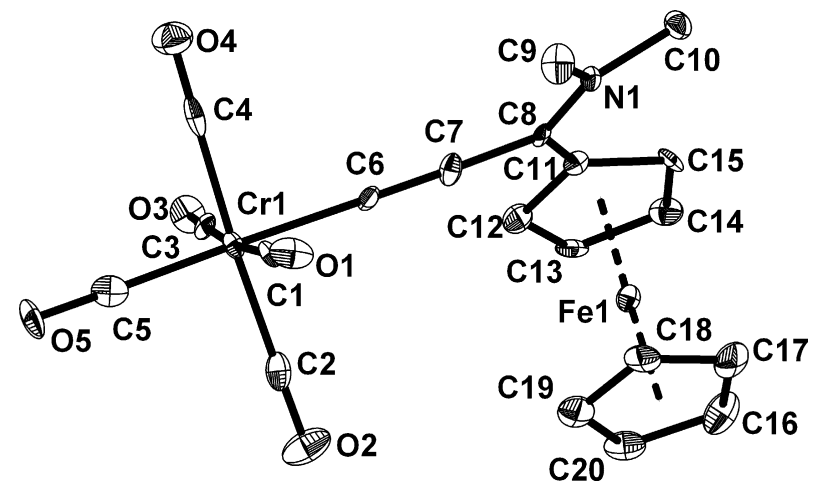

Fig. 1. Structure of complex 5a in the crystal (ellipsoids drawn at 50\% level, hydrogen atoms omitted for clarity).

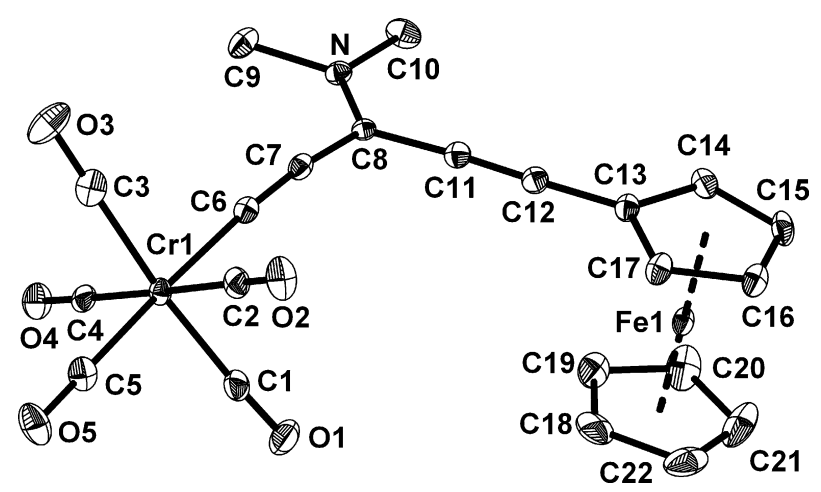

Fig. 2. Structure of complex 7a in the crystal (ellipsoids drawn at 50\% level, hydrogen atoms omitted for clarity).

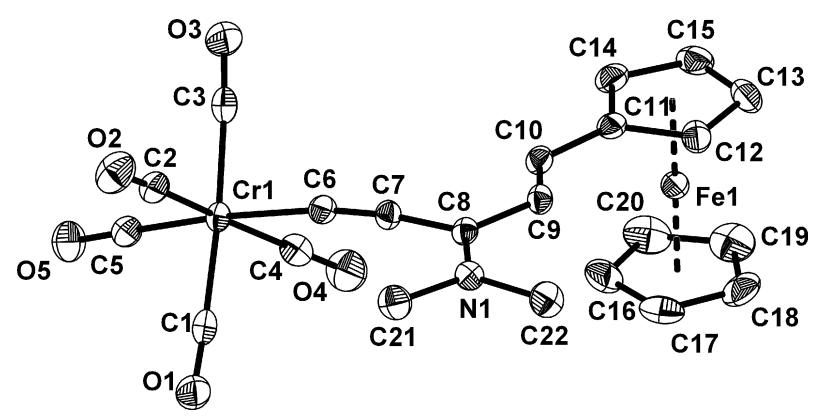

Fig. 3. Structure of complex 9a in the crystal (ellipsoids drawn at 50\% level, hydrogen atoms omitted for clarity).

Table 1

Selected distances $(\AA)$ and angles $\left(^{\circ}\right)$ in $\mathbf{5 a}, \mathbf{7 a}$, and 9a

\begin{tabular}{llll}
\hline & 5a & 7a & 9a \\
\hline Distances & & & \\
Cr(1) C(5) & $1.867(8)$ & $1.877(2)$ & $1.873(3)$ \\
Cr(1) C(cis) av. & 1.900 & 1.904 & 1.908 \\
Cr(1) C(6) & $2.022(7)$ & $2.009(2)$ & $2.048(3)$ \\
C(6) C(7) & $1.226(9)$ & $1.228(3)$ & $1.227(4)$ \\
C(7) C(8) & $1.409(9)$ & $1.399(3)$ & $1.418(4)$ \\
C(8) N(1) & $1.321(8)$ & $1.321(3)$ & $1.327(3)$ \\
Angles & & & \\
Cr(1) C(6) C(7) & $178.9(6)$ & $174.27(2)$ & $171.3(2)$ \\
C(6) C(7) C(8) & $173.5(7)$ & $171.3(2)$ & $172.2(3)$ \\
C(7) C(8) N(1) & $118.9(6)$ & $122.0(2)$ & $120.3(2)$ \\
\hline
\end{tabular}


The $\mathrm{Cr} C(6) \mathrm{C}(7) \mathrm{C}(8)$ fragment deviates from linearity, presumably due to interatomic interaction. The C6 C7 distance is short, shorter than that in the diphenylallenylidene complex 12 (1.249(3) A) [4b], however, slightly longer than in the diaminoallenylidene complex $\mathbf{1 3}$ (1.214(4) А) [7b]. Conversely, the Cr C6 and C7 C8 distances in 7a and 9a are significantly longer than in $\mathbf{1 2}$ (Cr C6 1.931(2) Å, C7 C8 1.358(3) A) but compare well with those in $\mathbf{1 3}$ (Cr C6 2.030(3) ̊, C7 C8 1.411(4) $\mathrm{A}$ ).<smiles>O=C(O)C=C=C=C(c1ccccc1)c1ccccc1</smiles>

12<smiles>CC(C)(C)OC=C=C=C1NCCN1CCN</smiles>

13
The C8 $\mathrm{N}$ distance in 7a, 9a, and $\mathbf{1 3}(1.324(3) \AA$ ) is likewise very similar. From these data it follows that the dimethylamino(ferrocenyl) unit strongly interacts with the $(\mathrm{CO})_{5} \mathrm{Cr}$ fragment (Scheme 10) and that the spacer linking $\mathrm{C}_{\gamma}$ and $\mathrm{Fc}$ only marginally influences the interaction.

The conclusion is confirmed by the pronounced trans influence of the allenylidene ligand in $\mathbf{5 a}, \mathbf{7 a}$, and $\mathbf{9 a}$, the trans-Cr $\mathrm{CO}$ distance being significantly shorter than the average of the cis-Cr $\mathrm{CO}$ distances $[1.87(1)$ versus $1.90(1) \AA(5 a), 1.877(2)$ versus $1.904(2) \AA(7 a), 1.873(3)$ versus $1.908(3) \AA(\mathbf{9 a})]$. The trans influence is similar to and only slightly smaller than that in 13 [1.866(3) versus $1.908 \AA$ ] whereas in the diphenylallenylidene complex $\mathbf{1 2}$ cis- and trans-Cr $\mathrm{CO}$ distances are similar, the trans-Cr CO bond (1.912(3) $\AA$ ) being even slightly longer than the average of the cis-Cr CO distances $(1.905 \AA$ ). In all complexes the cis-Cr $\mathrm{CO}$ distances are essentially the same, the difference resulting from the influence of the allenylidene ligand on the trans-Cr $\mathrm{CO}$ bond.

The C7 C8 bond in $7 \mathbf{a}$ is shorter than the $\mathrm{C}(8) \mathrm{C}(11)$ bond $(1.425(3) \AA)$ and considerably shorter than that expected for a $\mathrm{C}(\mathrm{sp}) \mathrm{C}\left(\mathrm{sp}^{2}\right)$ bond $(1.431 \AA$ [15]). Conversely, C6 C7 is longer than $\mathrm{C} 11 \mathrm{C} 12$. These are in accord with expectations based on the bonding model depicted in Scheme 10. In 9a the C9 C10 distance is longer $(1.347(4) \AA)$ than that usually observed for trans-substituted $(\mathrm{H}) \mathrm{C}=\mathrm{C}(\mathrm{H})$ bonds $(1.312 \AA[15])$ and the $\mathrm{C} 8 \mathrm{C} 9$ single bond $(1.469(3) \AA)$ is in between those observed for conjugated and unconjugated $\mathrm{C}\left(\mathrm{sp}^{2}\right) \mathrm{C}\left(\mathrm{sp}^{2}\right)$ single bonds [15] indicating interaction of the $\mathrm{C}_{5} \mathrm{H}_{4}$ unit and the allenylidene ligand.

The conclusions drawn from the solid-state structures are supported by the spectroscopic data. The $v(\mathrm{CO})$ absorptions in the IR spectra of all allenylidene complexes (Table 2) show the pattern expected for a local $C_{4 v}$ symme-

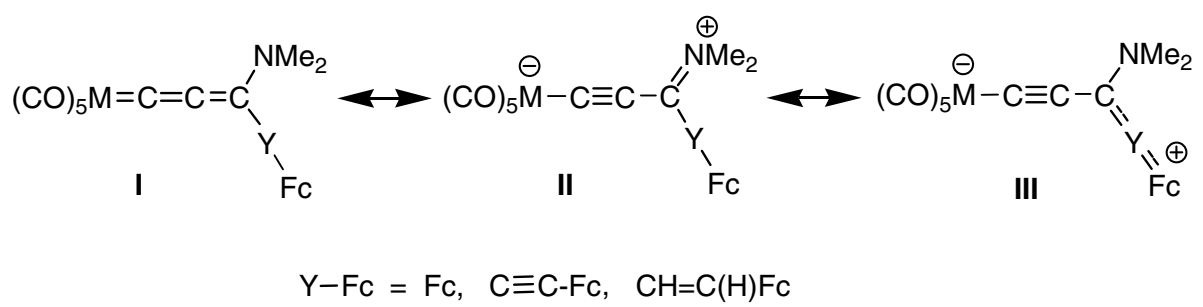

Scheme 10.

Table 2

Infrared data $(v(\mathrm{CO})$ and $v(\mathrm{CCC}))$ for $1 \mathbf{a} \mathbf{c}, \mathbf{2 a}, \mathbf{5 a}, 7 \mathbf{a}, \mathbf{9 a}$, and 11a $\mathbf{c}$

\begin{tabular}{|c|c|c|c|c|c|c|c|}
\hline & $\mathrm{M}$ & $\mathrm{R}^{1}$ & $\mathrm{R}^{2}$ & Solv. $^{\mathrm{a}}$ & $v(\mathrm{CO})$ & $v(\mathrm{CCC})$ & Ref. $^{\mathrm{b}}$ \\
\hline & $\mathrm{Cr}$ & $\mathrm{Ph}$ & $\mathrm{Ph}$ & $\mathrm{P}$ & $2067,1995,1974$ & 1930 & $4 b$ \\
\hline $1 \mathbf{a}$ & $\mathrm{Cr}$ & $\mathrm{Fc}$ & $\mathrm{Fc}$ & $\mathrm{P}$ & $2062,1949,1933$ & 1964 & t.w. \\
\hline $1 \mathbf{a}$ & $\mathrm{Cr}$ & $\mathrm{Fc}$ & $\mathrm{Fc}$ & $\mathrm{T}$ & $2062,1937,1918$ & 1961 & t.w. \\
\hline 1c & Mo & $\mathrm{Fc}$ & $\mathrm{Fc}$ & $\mathrm{P}$ & 2071, 1930, 1948 & 1964 & t.w. \\
\hline $2 a$ & $\mathrm{Cr}$ & $\mathrm{Fc}$ & $\mathrm{Ph}$ & $\mathrm{P}$ & 2061, 1933, 1960 & 1975 & t.w. \\
\hline $5 \mathbf{a}$ & $\mathrm{Cr}$ & $\mathrm{Fc}$ & $\mathrm{NMe}_{2}$ & $\mathrm{H}$ & 2071, 1944, 1934 & & t.w. \\
\hline $9 a$ & $\mathrm{Cr}$ & $\mathrm{NMe}_{2}$ & $\mathrm{CH}=\mathrm{C}(\mathrm{H}) \mathrm{Fc}$ & $\mathrm{T}$ & $2076,1929,1903$ & 2005 & t.w. \\
\hline $11 \mathrm{a}$ & $\mathrm{Cr}$ & $\mathrm{NEt}_{2}$ & $\mathrm{CMe}=\mathrm{CFc}_{2}$ & $\mathrm{P}$ & 1940,1931 & 1978 & t.w. \\
\hline 11b & W & $\mathrm{NEt}_{2}$ & $\mathrm{CMe}=\mathrm{CFc}_{2}$ & $\mathrm{P}$ & 1935,1925 & 1978 & t.w. \\
\hline \multirow[t]{2}{*}{$11 \mathrm{c}$} & Mo & $\mathrm{NEt}_{2}$ & $\mathrm{CMe}=\mathrm{CFc}_{2}$ & $\mathrm{P}$ & 1941,1930 & 1978 & t.w. \\
\hline & $\mathrm{Cr}$ & $\mathrm{NMe}_{2}$ & $\mathrm{NMe}_{2}$ & $\mathrm{~T}$ & $2078,1929,1903$ & 2014 & 5 \\
\hline
\end{tabular}

\footnotetext{
${ }^{\mathrm{a}} \mathrm{P}=$ pentane, $\mathrm{T}=\mathrm{THF}, \mathrm{H}=$ hexane.
}

b This work. 
try of the $(\mathrm{CO})_{5} \mathrm{M}$ fragment. The positions of the $v(\mathrm{CO})$ absorptions as well as of the $v(\mathrm{CCC})$ vibration are dependant on the substituents at $\mathrm{C}_{\gamma}$ indicating electronic communication between the terminal groups. The positions of the $v$ (CCC) absorption are in the range $19602006 \mathrm{~cm}^{-1}$ depending on the $\pi$-donor properties of the substituents. The $v(\mathrm{CCC})$ absorption is in between that of the complexes $\left[(\mathrm{CO})_{5} \mathrm{Cr}=\mathrm{C}=\mathrm{C}=\mathrm{C}\left(\mathrm{R}^{1}\right) \mathrm{R}^{2}\right]$ with $\mathrm{C}\left(\mathrm{R}^{1}\right) \mathrm{R}^{2}=\mathrm{CPh}_{2}$ $\left(1930 \mathrm{~cm}^{-1}\right.$ [4b]) and $\mathrm{C}\left(\mathrm{NMe}_{2}\right)_{2}\left(2014 \mathrm{~cm}^{-1}\right.$ [5]) and roughly shifts towards higher energy in the series $\mathrm{CPh}_{2}<$ $\mathrm{CFc}_{2}<\mathrm{C}(\mathrm{Fc}) \mathrm{Ph}<\mathrm{C}\left(\mathrm{NMe}_{2}\right) \mathrm{C} \equiv \mathrm{CFc} \approx \mathrm{C}\left(\mathrm{NMe}_{2}\right) \mathrm{CH}=\mathrm{CFc}_{2}$ $<\mathrm{C}\left(\mathrm{NMe}_{2}\right) \mathrm{Fc}<\mathrm{C}\left(\mathrm{NMe}_{2}\right)_{2}$. From the series an increasing triple bond character of the $\mathrm{C}_{\alpha} \mathrm{C}_{\beta}$ bond and an increasing contribution of the resonance forms II and III (see Scheme 10) to the overall bonding can be deduced. In accord with these conclusions is the shift of the resonance of the $\mathrm{C}_{\alpha}$ atom in the ${ }^{13} \mathrm{C}$ NMR spectrum towards higher field in the same series and the approximate inverse correlation of the force constant of the trans-CO vibration.

In summary, we have developed several independent synthetic pathways to ferrocene-substituted allenylidene complexes. These routes should also be applicable to the synthesis of bi- and trinuclear allenylidene complexes with other metal combinations. The spectroscopic data suggest that the carbon-rich bridging groups in these complexes are able to mediate electronic communication between the metal centres and that there is considerable interaction of the terminal metal ligand fragments [16].

\section{Experimental}

All operations were performed in an inert gas atmosphere (argon or nitrogen) using standard Schlenk techniques. Solvents were dried by distillation from $\mathrm{CaH}_{2}$ $\left(\mathrm{CH}_{2} \mathrm{Cl}_{2}\right), \mathrm{LiAlH}_{4}$ (petrol ether), and sodium/benzophenone ketyl (THF, $\mathrm{Et}_{2} \mathrm{O}$ ). The stationary phases used for chromatography [silica gel (Baker, silica gel for flash chromatography), neutral $\mathrm{Al}_{2} \mathrm{O}_{3}$ (Fluka, activity I), basic $\mathrm{Al}_{2} \mathrm{O}_{3} 90$ (Fluka, activity I)] was nitrogen-saturated. The yields refer to analytically pure compounds and are not optimized. Instrumentation: ${ }^{1} \mathrm{H}$ NMR and ${ }^{13} \mathrm{C}$ NMR spectra were recorded on a Bruker AC 250 spectrometer or on a Varian Inova 400 spectrometer at room temperature. Chemical shifts are reported relative to the residual solvent peaks. IR spectra were recorded on a Biorad FTS 60. MS measurements were carried out on a Finnigan MAT 312 instrument. The UV Vis spectra were recorded on a Hewlett Packard 8452A diode array spectrophotometer. The following compounds were prepared according to literature procedures: di(ferrocenyl)ketone [17], 1,1-diferrocenyl-3-(trimethylsilyl)-prop-2-in-ol [18], 1,1-diferrocenyl-3-prop-2-in-ol [18], 1-ferrocenyl-1-phenyl-prop-2-in-1-ol [19] and the complexes $\left[(\mathrm{CO})_{5} \mathrm{M}(\mathrm{THF})\right]$ [11], 3a [20], 6a [6], 8a [21] and formylferrocene [22] were prepared according to published methods. All other chemicals were used as obtained from commercial suppliers.

\subsection{Pentacarbonyl(3,3-bis[ferrocenyl]-1,2- propadienylidene) chromium (1a)}

At $-80^{\circ} \mathrm{C}$, a solution of $1.64 \mathrm{ml}(2.6 \mathrm{mmol})$ of $n$-BuLi (1.6 M solution in hexane) was added to a solution of $0.5 \mathrm{~g}$ (1.2 mmol) of 1,1-diferrocenylprop-2-in-1-ol in $14 \mathrm{ml}$ of THF. After $5 \mathrm{~min}$, cooling was removed and the orange solution was stirred for $30 \mathrm{~min}$. Then, $12 \mathrm{ml}(1.2 \mathrm{mmol})$ of a $0.1 \mathrm{M}$ solution of $\left[(\mathrm{CO})_{5} \mathrm{Cr}(\mathrm{THF})\right]$ in THF was added. Stirring was continued for $1 \mathrm{~h}$ at room temperature. The colour of the solution changed from orange to red-brown. The solvent was removed in vacuo. The resulting brown residue was dissolved at $-100{ }^{\circ} \mathrm{C}$ in $18 \mathrm{ml}$ of toluene/ $\mathrm{CH}_{2} \mathrm{Cl}_{2}(1: 5)$ and $0.62 \mathrm{ml}(1.2 \mathrm{mmol})$ of phosgene $(1.92 \mathrm{M}$ solution in toluene) (Caution: Phosgene is highly toxic and should only be handled with care in a well-vented fume hood!) was added. The solution was stirred for $1 \mathrm{~h}$ at $-80{ }^{\circ} \mathrm{C}$ to $-60{ }^{\circ} \mathrm{C}$ (temperature slowly increasing) and for $30 \mathrm{~min}$ at room temperature At $-40{ }^{\circ} \mathrm{C}$ the solution turned dark blue. The solvent was again removed and the residue was chromatographed at $-20{ }^{\circ} \mathrm{C}$ on silica or neutral $\mathrm{Al}_{2} \mathrm{O}_{3}$. With pentane $/ \mathrm{CH}_{2} \mathrm{Cl}_{2} / \mathrm{Et}_{2} \mathrm{O}$ (7:2:1) first a yellow band $\left(\left[\mathrm{Cr}(\mathrm{CO})_{6}\right]\right)$ and then a blue band containing the allenylidene complex was eluted. Blue-violet solid. Yield: $0.25 \mathrm{~g}(0.47 \mathrm{mmol}, 39 \%)$. Mp $130^{\circ} \mathrm{C}$ (dec). IR (petrol ether, $\left.\mathrm{cm}^{-1}\right): v(\mathrm{CO}) 2062 \mathrm{w}, 1949 \mathrm{~m}, 1933 \mathrm{~m}$; $v$ (CCC) $1964 \mathrm{~m}$; IR (THF, $\left.\mathrm{cm}^{-1}\right): v(\mathrm{CO}) 2062 \mathrm{vw}$, $1937 \mathrm{~s}, 1918$ vs, $v(\mathrm{CCC}) 1961 \mathrm{~m} .{ }^{1} \mathrm{H}$ NMR $(400 \mathrm{MHz}$, acetone- $\left.d_{6}\right): \delta 4.23\left(\mathrm{~s}, 10 \mathrm{H}, \mathrm{C}_{5} \mathrm{H}_{5}\right), 4.94\left(\mathrm{~s}, 4 \mathrm{H}, \mathrm{C}_{5} \mathrm{H}_{4}\right)$, $5.13\left(\mathrm{~s}, 4 \mathrm{H}, \mathrm{C}_{5} \mathrm{H}_{4}\right) \cdot{ }^{13} \mathrm{C}$ NMR $\left(100.6 \mathrm{MHz}\right.$, acetone- $\left.d_{6}\right): \delta$ $73.0\left(\mathrm{C}_{5} \mathrm{H}_{5}\right), 75.9,76.5,77.5,87.0\left(\mathrm{C}_{5} \mathrm{H}_{4}\right), 162.0\left(\mathrm{C}_{\beta}\right)$, $168.5\left(\mathrm{C}_{\gamma}\right), 217.1$ (cis-CO), 230.9 (trans-CO), $265.5\left(\mathrm{C}_{\alpha}\right)$. $\mathrm{UV}$ Vis $\left(\lambda_{\max }, \mathrm{nm}(\log \varepsilon)\right.$ [pentane]): 768 (4.40), 580 (3.96). MAS (FAB), m/z: $598\left[\mathrm{M}^{+}\right], 542\left[(\mathrm{M}-2 \mathrm{CO})^{+}\right]$, $486\left[(\mathrm{M}-4 \mathrm{CO})^{+}\right], 458\left[(\mathrm{M}-5 \mathrm{CO})^{+}\right]$. Anal. Calc. for $\mathrm{C}_{28} \mathrm{H}_{18} \mathrm{CrFe}_{2} \mathrm{O}_{5}$ (598.1): C, 56.23; H, 3.03. Found: C, $56.36 ; \mathrm{H}, 3.19 \%$.

Complex 1a was also obtained from (a) $\mathbf{5 a}$ and 5 equiv. of freshly prepared ferrocenyllithium in THF or (b) dimethylamino(methoxy)allenylidene complex $\mathbf{6 a}$ and 5 equiv. of freshly prepared ferrocenyllithium in THF. After stirring these solutions overnight, the solvent was removed and the residue recrystallized from pentane/dichloromethane.

\subsection{Pentacarbonyl(3,3-bis[ferrocenyl]-1,2- propadienylidene)molybdenum (1b)}

The procedure for the synthesis of $\mathbf{1 b}$ is essentially analogous to that of 1a. Deviation: After addition of phosgene the solution was stirred for $30 \mathrm{~min}$ at $-60^{\circ} \mathrm{C}$ and for 1 $5 \mathrm{~min}$ at room temperature. The colour turned deep blue. Removal of the solvent at $-50{ }^{\circ} \mathrm{C}$ and chromatography at $-40{ }^{\circ} \mathrm{C}$ on basic $\mathrm{Al}_{2} \mathrm{O}_{3}$ with pentane $/ \mathrm{CH}_{2} \mathrm{Cl}_{2} / \mathrm{Et}_{2} \mathrm{O}$ (10:3:1) afforded [W(CO) 6 ] (first band) and then 1b (blue band). Complex $1 \mathrm{~b}$ was stable only below $-40^{\circ} \mathrm{C}$. Blue solid. Yield: ca. $0.1 \mathrm{~g}(0.24 \mathrm{mmol}, 20 \%)$. IR (pentane, $\left.\mathrm{cm}^{-1}\right): v(\mathrm{CO}) \quad 2071 \mathrm{w}, 1930 \mathrm{vs}, 1948 \mathrm{~m} ; v(\mathrm{CCC}) 1964$ 
m. ${ }^{1} \mathrm{H}$ NMR $\left(250 \mathrm{MHz}, \mathrm{CDCl}_{3}\right): \delta 4.23\left(\mathrm{~s}, 10 \mathrm{H}, \mathrm{C}_{5} \mathrm{H}_{5}\right)$, $4.44\left(\mathrm{~m}, 4 \mathrm{H}, \mathrm{C}_{5} \mathrm{H}_{4}\right), 4.78\left(\mathrm{~m}, 4 \mathrm{H}, \mathrm{C}_{5} \mathrm{H}_{4}\right)$. UV Vis $\left(\lambda_{\max }\right.$, $\mathrm{nm}(\log \varepsilon)$ [pentane]): 747 (4.52), 575 (4.20), 349 (4.46), 257 (4.82), 235 (4.89), 207 (4.96). MAS (FAB), $m / z$ (rel. $\left.{ }^{98} \mathrm{Mo}\right): 644\left[\mathrm{M}^{+}\right], 616\left[(\mathrm{M}-\mathrm{CO})^{+}\right], 588\left[(\mathrm{M}-2 \mathrm{CO})^{+}\right], 504$ $\left[(\mathrm{M}-5 \mathrm{CO})^{+}\right] . \mathrm{C}_{28} \mathrm{H}_{18} \mathrm{MoFe}_{2} \mathrm{O}_{5}$ (642.1).

\subsection{Pentacarbonyl(3,3-bis[ferrocenyl]-1,2- propadienylidene) tungsten (1c)}

The procedure for the synthesis of $\mathbf{1 c}$ is analogous to that of $\mathbf{1 b}$. Blue solid stable only below $-40{ }^{\circ} \mathrm{C}$. Yield: ca. $0.22 \mathrm{~g}(0.3 \mathrm{mmol}, 25 \%)$. IR (pentane, $\left.\mathrm{cm}^{-1}\right): v(\mathrm{CO})$ 2072 w, 1927 vs, $1941 \mathrm{~m} ; v(\mathrm{CCC}) 1957 \mathrm{~m} .{ }^{1} \mathrm{H}$ NMR $\left(250 \mathrm{MHz}, \mathrm{CDCl}_{3}\right): \delta 4.34\left(\mathrm{~s}, 10 \mathrm{H}, \mathrm{C}_{5} \mathrm{H}_{5}\right), 5.09(\mathrm{~m}, 4 \mathrm{H}$, $\left.\mathrm{C}_{5} \mathrm{H}_{4}\right), 5.22\left(\mathrm{~m}, 4 \mathrm{H}, \mathrm{C}_{5} \mathrm{H}_{4}\right)$. UV Vis $\left(\lambda_{\max }, \mathrm{nm}(\log \varepsilon)\right.$ [pentane]): 739 (5.09), 566 (4.67), 350 (5.01), 255 (5.37), 233 (5.43), 202 (5.58). MS (FAB), m/z: $730\left[\mathrm{M}^{+}\right], 702$ $\left[\begin{array}{lllll}\left.(\mathrm{M}-\mathrm{CO})^{+}\right], & 646 & {\left[(\mathrm{M}-3 \mathrm{CO})^{+}\right],} & 590 & {\left[(\mathrm{M}-5 \mathrm{CO})^{+}\right] .}\end{array}\right.$ $\mathrm{C}_{28} \mathrm{H}_{18} \mathrm{WFe}_{2} \mathrm{O}_{5}$ (730.0).

\subsection{Pentacarbonyl[3-ferrocenyl-3-phenyl-1,2- propadienylidene ]chromium (2a)}

Complex 2a was synthesized analogously to $\mathbf{1 b}$ starting from $0.38 \mathrm{~g}(1.2 \mathrm{mmol})$ of 1-ferrocenyl-1-phenyl-prop-2in-1-ol. Instead of phosgene, neutral $\mathrm{Al}_{2} \mathrm{O}_{3}(5 \mathrm{~g}$ in $60 \mathrm{ml}$ of $\mathrm{CH}_{2} \mathrm{Cl}_{2}$ ) was used at $-40{ }^{\circ} \mathrm{C}$ in the desoxygenation step. The complex adsorbed on $\mathrm{Al}_{2} \mathrm{O}_{3}$ was then eluted (after filtration) at $-35^{\circ} \mathrm{C}$ with $\mathrm{CH}_{2} \mathrm{Cl}_{2}$. The complex thus obtained after removal of the solvent was contaminated with $\left[\mathrm{Cr}(\mathrm{CO})_{6}\right]$. Subsequent chromatography on basic $\mathrm{Al}_{2} \mathrm{O}_{3}$ at $-35^{\circ} \mathrm{C}$ with pentane $/ \mathrm{CH}_{2} \mathrm{Cl}_{2}$ (4:1) yielded ca. $0.23 \mathrm{~g}(0.45 \mathrm{mmol}, 38 \%)$ of thermally labile complex $2 \mathrm{a}$ stable only below $-40{ }^{\circ} \mathrm{C}$. IR (pentane, $\mathrm{cm}^{-1}$ ): $v(\mathrm{CO})$ $2061 \mathrm{w}, 1933 \mathrm{vs}, 1960 \mathrm{~m}$; $v(\mathrm{CCC}) 1975 \mathrm{~m} .{ }^{1} \mathrm{H}$ NMR $\left(250 \mathrm{MHz}, \mathrm{CDCl}_{3}\right): \delta 4.25\left(\mathrm{~s}, 10 \mathrm{H}, \mathrm{C}_{5} \mathrm{H}_{5}\right), 5.10(\mathrm{~m}, 4 \mathrm{H}$, $\left.\mathrm{C}_{5} \mathrm{H}_{4}\right), 5.21\left(\mathrm{~m}, 4 \mathrm{H}, \mathrm{C}_{5} \mathrm{H}_{4}\right), 7.83(\mathrm{~m}, 1 \mathrm{H}, \mathrm{Ph}), 7.80(\mathrm{~m}$, $1 \mathrm{H}, \mathrm{Ph}), 7.51(\mathrm{~m}, 1 \mathrm{H}, \mathrm{Ph}), 7.40(\mathrm{~m}, 2 \mathrm{H}, \mathrm{Ph}) . \mathrm{UV}$ Vis $\left(\lambda_{\max }\right.$, $\mathrm{nm}(\log \varepsilon)$ [pentane]): 754 (5.50), 618 (5.30), 350 (5.30), 280 (5.92), 229 (6.52).

\subsection{Pentacarbonyl(3-dimethylamino-1-ethoxy-3-ferrocenyl- prop-2-en-ylidene) chromium (4a)}

At room temperature, an excess of dimethylamine ( $43 \%$ in aqueous solution) was slowly added to a solution of the ethoxy(ferrocenylethynyl)carbene complex 3a in THF. The dark violet solution turned light orange. The progress of the reaction was followed by TLC. After completion of the reaction, the solvent was removed in vacuo and the residue was chromatographed at $-20^{\circ} \mathrm{C}$ on silica with dichloromethane/pentane mixtures. The yellow band containing 4a was eluted. Yellow crystals. Yield: $0.39 \mathrm{~g}(0.77 \mathrm{mmol}$, $48 \%$ ). M.p. $130^{\circ} \mathrm{C}$ (dec.). IR (THF, $\mathrm{cm}^{-1}$ ): v(CO) 2041 m, 1958 w, 1916 vs, 1899 m. ${ }^{1} \mathrm{H} \mathrm{NMR}\left(400 \mathrm{MHz}, \mathrm{CDCl}_{3}\right)$ : $\delta 1.38\left(\mathrm{t}, J \quad 7.1 \mathrm{~Hz}, 3 \mathrm{H}, \mathrm{CH}_{3}\right), 3.08\left(\mathrm{~s}, 6 \mathrm{H}, \mathrm{NCH}_{3}\right), 4.28$ $\left(\mathrm{s}, 5 \mathrm{H}, \mathrm{C}_{5} \mathrm{H}_{5}\right), 4.49\left(\mathrm{t}, J 1.9 \mathrm{~Hz}, 2 \mathrm{H}, \mathrm{C}_{5} \mathrm{H}_{4}\right), 4.56(\mathrm{t}$, $\left.J \quad 1.8 \mathrm{~Hz}, 2 \mathrm{H}, \mathrm{C}_{5} \mathrm{H}_{4}\right), 4.59\left(\mathrm{q}, J \quad 7.1 \mathrm{~Hz}, 2 \mathrm{H}, \mathrm{CH}_{2}\right)$, $6.84(\mathrm{~s}, 1 \mathrm{H}, \mathrm{C}=\mathrm{CH}) .{ }^{13} \mathrm{C}$ NMR $\left(400 \mathrm{MHz}, \mathrm{CDCl}_{3}\right): \delta$ $16.1\left(\mathrm{NCH}_{3}\right), 45.3\left(\mathrm{CH}_{3}\right), 71.1\left(\mathrm{C}_{5} \mathrm{H}_{5}\right), 71.3\left(2 \mathrm{C}, \mathrm{C}_{5} \mathrm{H}_{4}\right)$, $72.7\left(2 \mathrm{C}, \mathrm{C}_{5} \mathrm{H}_{4}\right), 73.2\left(1 \mathrm{C}, \mathrm{C}_{5} \mathrm{H}_{4}\right), 79.7(\mathrm{CH}=\mathrm{C}), 117.4$ ( $C \mathrm{Fc}$ ), $162.1(\mathrm{Cr}=C), 220.3$ (cis-CO), 224.7 (trans-CO). $\mathrm{UV}$ Vis $\lambda_{\max }, \mathrm{nm}(\log \varepsilon)$ [solvent]: 497 (3.738) $\left[\mathrm{CH}_{2} \mathrm{Cl}_{2}\right]$; 520 (3.469) [DMF]; 515 (3.695) [THF]. MAS (FAB), $m / z$ : $503 \quad\left[\mathrm{M}^{+}\right], \quad 475\left[(\mathrm{M}-\mathrm{CO})^{+}\right], \quad 447 \quad\left[(\mathrm{M}-2 \mathrm{CO})^{+}\right], 419$ $\left[(\mathrm{M}-3 \mathrm{CO})^{+}\right], 391\left[(\mathrm{M}-4 \mathrm{CO})^{+}\right], 363\left[(\mathrm{M}-5 \mathrm{CO})^{+}\right]$. Anal . Calc. for $\mathrm{C}_{22} \mathrm{H}_{21} \mathrm{CrFeNO}_{6}(503.25): \mathrm{C}, 52.51 ; \mathrm{H}, 4.21 ; \mathrm{N}$, 2.78. Found: C, 52.57; H, 4.21; N, 2.92\%.

\subsection{Pentacarbonyl(3-dimethylamino-3-ferrocenyl-1,2- propadienylidene) chromium (5a)}

At $0{ }^{\circ} \mathrm{C}$, a solution of $0.15 \mathrm{mmol}$ of $\mathrm{BCl}_{3}(1 \mathrm{M}$ in hexane) was added dropwise to a solution of $0.15 \mathrm{mmol}$ of 4a in $50 \mathrm{ml}$ of diethyl ether. The orange solution slowly turned red. After stirring the solution for $30 \mathrm{~min}$, the solvent was removed in vacuo. The remaining oily residue was recrystallized from pentane/dichloromethane, giving dark red crystals of 5a. Yield: $0.15 \mathrm{~g}(0.11 \mathrm{mmol}, 73 \%)$. M.p. $125^{\circ} \mathrm{C}$ (dec.). IR (hexane, $\mathrm{cm}^{-1}$ ): v(CO) $2071 \mathrm{w}$, $1944 \mathrm{~s}, 1934$ vs; $\left(\mathrm{THF}, \mathrm{cm}^{-1}\right): v(\mathrm{CO}) 2079 \mathrm{vw}, 1932 \mathrm{vs}$, $1915 \mathrm{~m}, v(\mathrm{CCC}) 2006 \mathrm{~m} .{ }^{1} \mathrm{H}$ NMR $(400 \mathrm{MHz}$, acetone$\left.d_{6}\right): \delta 3.39(\mathrm{~s}, 3 \mathrm{H}, \mathrm{NMe}), 3.62(\mathrm{~s}, 3 \mathrm{H}, \mathrm{NMe}), 4.34(\mathrm{~s}, 5 \mathrm{H}$, $\left.\mathrm{C}_{5} \mathrm{H}_{5}\right), 4.65\left(\mathrm{~s}, 2 \mathrm{H}, \mathrm{C}_{5} \mathrm{H}_{4}\right), 4.89\left(\mathrm{~s}, 2 \mathrm{H}, \mathrm{C}_{5} \mathrm{H}_{4}\right) .{ }^{13} \mathrm{C} \mathrm{NMR}$ $\left(100.6 \mathrm{MHz}, \mathrm{CDCl}_{3}\right): \delta 38.7,42.7\left(\mathrm{NMe}_{2}\right), 72.6(\mathrm{Cp})$, $71.9(\mathrm{Cp}), 73.3(\mathrm{Cp}), 105.1\left(\mathrm{C}_{\beta}\right), 167.7\left(\mathrm{C}_{\gamma}\right), 196.2\left(\mathrm{C}_{\alpha}\right)$, 218.2 (cis-CO), 223.7 (trans-CO). MS (FAB), m/z: 457 $\left[\mathrm{M}^{+}\right], \quad 401 \quad\left[(\mathrm{M}-2 \mathrm{CO})^{+}\right], \quad 373 \quad\left[(\mathrm{M}-3 \mathrm{CO})^{+}\right], \quad 345$ $\left[(\mathrm{M}-4 \mathrm{CO})^{+}\right], \quad 317 \quad\left[(\mathrm{M}-5 \mathrm{CO})^{+}\right]$. Anal. Calc. for $\mathrm{C}_{20} \mathrm{H}_{15} \mathrm{CrFeNO}_{5}$ (457.2): C, 52.54, H, 3.31, N, 3.06. Found: C, 52.64, H, 3.84, N, 2.80\%.

\subsection{Pentacarbonyl(3-dimethylamino-3-ferrocenylethynyl- 1,2-propadienylidene) chromium (7a)}

At $-80{ }^{\circ} \mathrm{C}, n$-BuLi $(1.65 \mathrm{mmol}, 1.04 \mathrm{ml}$ of a $1.6 \mathrm{M}$ solution in hexane) was added within ca. $1 \mathrm{~min}$ to $0.35 \mathrm{~g}$ $(1.65 \mathrm{mmol})$ of ethynylferrocene in $50 \mathrm{ml}$ of THF. The solution was stirred for $1 \mathrm{~h}$ at $-80^{\circ} \mathrm{C}$ and then added at $-80^{\circ} \mathrm{C}$ to a solution of $0.5 \mathrm{~g}(1.65 \mathrm{mmol})$ of $6 \mathrm{a}$ in $50 \mathrm{ml}$ of THF. Immediately afterwards, $0.21 \mathrm{ml}(1.65 \mathrm{mmol})$ of trimethylchlorosilane was added. After $5 \mathrm{~min}$ at $-80^{\circ} \mathrm{C}$, the solution was filtered over silica gel at $-20^{\circ} \mathrm{C}$. With ca. $500 \mathrm{ml}$ of $\mathrm{CH}_{2} \mathrm{Cl}_{2}$ a dark blue solution was eluted. The solvent was removed in vacuo and the residue was chromatographed at $-20^{\circ} \mathrm{C}$ on silica using pentane/ dichloromethane mixtures (ratio decreasing from 4:1 to $1: 1)$ as eluants. The product was isolated as a violet band. Removal of the solvent yielded $0.41 \mathrm{~g}(0.85 \mathrm{mmol} ; 52 \%)$ of $7 \mathbf{a}$ as a red solid. M.p. $98{ }^{\circ} \mathrm{C}$ (dec.). IR (THF, $\mathrm{cm}^{-1}$ ): $v(\mathrm{CO}) \quad 2078 \mathrm{vw}, 1935 \mathrm{vs}, 1913 \mathrm{~s} ; v(\mathrm{CCC}) 2007 \mathrm{~s} .{ }^{1} \mathrm{H}$ NMR $\left(400 \mathrm{MHz}\right.$, acetone- $\left.d_{6}\right): \delta 3.46\left(\mathrm{~s}, 3 \mathrm{H}, \mathrm{NCH}_{3}\right) 3.50$ $\left(\mathrm{s}, 3 \mathrm{H}, \mathrm{NCH}_{3}\right), 4.28\left(\mathrm{~s}, 5 \mathrm{H}, \mathrm{C}_{5} \mathrm{H}_{5}\right), 4.46\left(\mathrm{~s}, 2 \mathrm{H}, \mathrm{C}_{5} \mathrm{H}_{4}\right)$, 
$4.62\left(\mathrm{~s}, 2 \mathrm{H}, \mathrm{C}_{5} \mathrm{H}_{4}\right) .{ }^{13} \mathrm{C}$ NMR $\left(100.6 \mathrm{MHz}\right.$, acetone- $\left.d_{6}\right): \delta$ $41.9,42.4\left(\mathrm{NCH}_{3}\right), 71.3\left(\mathrm{C}_{5} \mathrm{H}_{5}\right), 71.8\left(2 \mathrm{C}, \mathrm{C}_{5} \mathrm{H}_{4}\right), 72.7$ $\left(2 \mathrm{C}, \mathrm{C}_{5} \mathrm{H}_{4}\right), \quad 73.2\left(1 \mathrm{C}, \mathrm{C}_{5} \mathrm{H}_{4}\right), 82.4 \quad(\mathrm{C} \equiv \mathrm{CFc}), 102.2$ $(\mathrm{C} \equiv C \mathrm{Fc}), 105.5\left(\mathrm{C}_{\beta}\right), 148.6\left(\mathrm{C}_{\gamma}\right), 209.5\left(\mathrm{C}_{\alpha}\right), 217.8$ (cis$\mathrm{CO}), 224.0\left(\right.$ trans-CO). UV Vis $\left(\lambda_{\max }, \mathrm{nm}(\log \varepsilon)\right.$ [solvent]): 571 (4.178) $\left[\mathrm{CHCl}_{3}\right] ; 555$ (4.169) $\left[\mathrm{CH}_{2} \mathrm{Cl}_{2}\right] ; 513$ (4.152) [DMF]. MS (FAB) $m / z: 481\left[\mathrm{M}^{+}\right], 369\left[(\mathrm{M}-4 \mathrm{CO})^{+}\right], 341$ $\left[(\mathrm{M}-5 \mathrm{CO})^{+}\right], 289 \quad\left[(\mathrm{M}-5 \mathrm{CO}-\mathrm{Cr})^{+}\right]$. Anal. Calc. for $\mathrm{C}_{22} \mathrm{H}_{15} \mathrm{CrFeNO}_{5}$ (481.2): C, 54.91; H, 3.14; N, 2.91. Found: C, 54.80; H, 3.28; N 2.97\%.

\subsection{Pentacarbonyl(3-dimethylamino-5-E-ferrocenyl-1,2,4- pentatrienylidene) chromium $(\mathbf{9 a})$}

At room temperature, $1 \mathrm{mmol}$ of formylferrocene was added to a solution of $0.28 \mathrm{~g}(1 \mathrm{mmol})$ of $\mathbf{8 a}$ in $10 \mathrm{ml}$ of $\mathrm{Et}_{3} \mathrm{~N} / \mathrm{THF}$ (1:1). The solution was stirred for $30 \mathrm{~min}$. Then, $0.26 \mathrm{ml}(3 \mathrm{mmol})$ of $\mathrm{TMSCl}$ was added. Stirring was continued. The solution slowly turned dark red. After $17 \mathrm{~h}$, the reaction mixture was chromatographed at $-20{ }^{\circ} \mathrm{C}$ on silica with pentane/THF mixtures (polarity increasing). With THF a red band was eluted containing 9a. Removal of the solvent in vacuo afforded $0.20 \mathrm{~g}(0.41 \mathrm{mmol}, 41 \%)$ of 9a. Dark red crystals. M.p. $115^{\circ} \mathrm{C}$ (dec.). IR (THF, $\mathrm{cm}^{-1}$ ): $v(\mathrm{CO}) \quad 2076 \mathrm{vw}, 1929 \mathrm{vs}, 1903 \mathrm{~m} ; v(\mathrm{CCC}) 2005 \mathrm{~m} .{ }^{1} \mathrm{H}$ NMR (400 MHz, acetone- $\left.d_{6}\right): \delta 3.50\left(\mathrm{~s}, 3 \mathrm{H}, \mathrm{NCH}_{3}\right), 3.66$ $\left(\mathrm{s}, 3 \mathrm{H}, \mathrm{NCH}_{3}\right), 4.24\left(\mathrm{~s}, 5 \mathrm{H}, \mathrm{C}_{5} \mathrm{H}_{5}\right), 4.66(\mathrm{t}, J 1.8 \mathrm{~Hz}$, $\left.2 \mathrm{H}, \mathrm{C}_{5} \mathrm{H}_{4}\right), 4.78\left(\mathrm{t}, J 1.8 \mathrm{~Hz}, 2 \mathrm{H}, \mathrm{C}_{5} \mathrm{H}_{4}\right), 6.94(\mathrm{~d}$, $J \quad 14.6 \mathrm{~Hz}, 1 \mathrm{H}, \mathrm{C} H=\mathrm{CHFc}), 8.16(\mathrm{~d}, J 14.6 \mathrm{~Hz}, 1 \mathrm{H}$, $\mathrm{CH}=\mathrm{CHFc}) .{ }^{13} \mathrm{C}$ NMR $\left(100.6 \mathrm{MHz}\right.$, acetone- $\left.d_{6}\right): \delta 41.6$ $\left(\mathrm{NCH}_{3}\right), 46.4\left(\mathrm{NCH}_{3}\right), 71.6\left(\mathrm{C}_{5} \mathrm{H}_{5}\right), 71.8\left(\mathrm{C}_{5} \mathrm{H}_{4}\right), 74.6$ $\left(\mathrm{C}_{5} \mathrm{H}_{4}\right), 80.8\left(\mathrm{C}_{5} \mathrm{H}_{4}\right), 113.9\left(\mathrm{C}_{\beta}\right), 117.1(\mathrm{CH}=\mathrm{CHFc})$, $139.1(\mathrm{CH}=\mathrm{CHFc}), 154.2\left(\mathrm{C}_{\gamma}\right), 197.0\left(\mathrm{C}_{\alpha}\right), 220.5\left(\mathrm{CO}_{\text {cis }}\right)$, $225.1\left(\mathrm{CO}_{\text {trans }}\right)$. UV Vis $\left(\lambda_{\max }, \mathrm{nm}(\log \varepsilon)\right.$ [solvent]): 562 (3.891) $\quad\left[\mathrm{CHCl}_{3}\right] ; \quad 527 \quad$ (3.864) $\quad\left[\mathrm{CH}_{2} \mathrm{Cl}_{2}\right] ; \quad 492 \quad$ (4.260) [DMF]. MS (FAB) $m / z: 482\left[(\mathrm{M}-\mathrm{H})^{+}\right], 427\left[(\mathrm{M}-2 \mathrm{CO})^{+}\right]$, $399\left[(\mathrm{M}-3 \mathrm{CO})^{+}\right], 371\left[(\mathrm{M}-4 \mathrm{CO})^{+}\right], 343\left[(\mathrm{M}-5 \mathrm{CO})^{+}\right]$. $\mathrm{C}_{22} \mathrm{H}_{17} \mathrm{CrFeNO}_{5}$ (483.2).

\subsection{Pentacarbonyl [3,3-diferrocenyl-1-( $N, N$ - dimethylamino) prop-2-enylidene ] chromium (10a)}

At $-45{ }^{\circ} \mathrm{C}, 10$ equiv. of $\mathrm{HNMe}_{2}(0.5 \mathrm{ml}, \sim 12 \mathrm{mmol})$ was added to a solution of $0.35 \mathrm{~g}(0.6 \mathrm{mmol})$ of $1 \mathrm{a}$ in $20 \mathrm{ml}$ of $\mathrm{CH}_{2} \mathrm{Cl}_{2}$. The deep blue solution turned green and then yellow. The reaction was complete within $10 \mathrm{~min}$. The solvent was removed in vacuo. The residue was chromatographed at $-20{ }^{\circ} \mathrm{C}$ on neutral alumina. With pentane $/ \mathrm{CH}_{2} \mathrm{Cl}_{2}$ (9:2) a yellow band was eluted. Removal of the solvent afforded $0.38 \mathrm{~g}(0.59 \mathrm{mmol}, 98 \%)$ of $\mathbf{1 0 a}$ as a yellow powder. IR (pentane, $\mathrm{cm}^{-1}$ ): $v(\mathrm{CO}) 2052 \mathrm{w}, 1967 \mathrm{w}, 1933 \mathrm{~s}, 1928 \mathrm{~s}$, sh. ${ }^{1} \mathrm{H}$ NMR $\left(250 \mathrm{MHz}, \mathrm{CDCl}_{3}\right): \delta 3.07(\mathrm{~s}, 3 \mathrm{H}, \mathrm{Me}), 3.77$ $(\mathrm{s}, 3 \mathrm{H}, \mathrm{Me}), 4.12\left(\mathrm{~s}, 5 \mathrm{H}, \mathrm{C}_{5} \mathrm{H}_{5}\right), 4.22\left(\mathrm{~s}, 5 \mathrm{H}, \mathrm{C}_{5} \mathrm{H}_{5}\right), 4.31$ $\left(\mathrm{m}, 6 \mathrm{H}, \mathrm{C}_{5} \mathrm{H}_{4}\right), 4.73\left(\mathrm{~s}, 1 \mathrm{H}, \mathrm{C}_{5} \mathrm{H}_{4}\right), 4.83\left(\mathrm{~s}, 1 \mathrm{H}, \mathrm{C}_{5} \mathrm{H}_{4}\right)$, $7.07(\mathrm{~s}, 1 \mathrm{H},=\mathrm{CH}) .{ }^{13} \mathrm{C}$ NMR $\left(62 \mathrm{MHz}, \mathrm{CDCl}_{3}\right): \delta 45.3$, $50.4(\mathrm{Me}), 67.8,68.0,68.1,68.4,68.7,68.8,69.0,69.6$, 83.5, 87.6 $\left(\mathrm{C}_{5} \mathrm{H}_{4}\right), 68.9,69.3\left(\mathrm{C}_{5} \mathrm{H}_{5}\right), 124.4\left(\mathrm{C}_{\gamma}\right), 135.4$
$\left(\mathrm{C}_{\beta}\right), 217.4\left(\mathrm{CO}_{\text {cis }}\right), 223.2\left(\mathrm{CO}_{\text {trans }}\right), 267.7\left(\mathrm{C}_{\alpha}\right) . \mathrm{MS}(\mathrm{EI}$, $70 \mathrm{EV}) \mathrm{m} / z: 643\left[\mathrm{M}^{+}\right], 615\left[(\mathrm{M}-\mathrm{CO})^{+}\right], 587\left[(\mathrm{M}-2 \mathrm{CO})^{+}\right]$, $559\left[(\mathrm{M}-3 \mathrm{CO})^{+}\right], \quad 503\left[(\mathrm{M}-5 \mathrm{CO})^{+}\right] . \mathrm{C}_{30} \mathrm{H}_{25} \mathrm{CrFe}_{2} \mathrm{NO}_{5}$ (643.2).

\subsection{Pentacarbonyl [3,3-diferrocenyl-1-( $N, N$ - dimethylamino) prop-2-enylidene Jmolybdenum (10b)}

The reaction of $0.39 \mathrm{~g}(0.6 \mathrm{mmol})$ of $\mathbf{1 b}$ with $\mathrm{HNMe}_{2}$ was carried out analogously to that of 1a. After addition of the amine the solution was stirred for approx. $4 \mathrm{~h}$ at $-10{ }^{\circ} \mathrm{C}$ to $-5^{\circ} \mathrm{C}$. For the purification of $10 \mathrm{~b}$ see 10a. Yield $0.25 \mathrm{~g} \quad(0.36 \mathrm{mmol}, \quad 60 \%) . \quad$ IR (pentane, $\left.\quad \mathrm{cm}^{-1}\right)$ : $v(\mathrm{CO}) 2061 \mathrm{w}, 1972 \mathrm{w}, 1939 \mathrm{~s}$,sh. IR (pentane, $\mathrm{cm}^{-1}$ ): $v(\mathrm{CO}) 1940$ vs, $1931 \mathrm{~s} ; v(\mathrm{CCC}) \quad 1978$ w. 1933 vs. ${ }^{1} \mathrm{H}$ NMR $\left(250 \mathrm{MHz}, \mathrm{CDCl}_{3}\right): \delta 3.06(\mathrm{~d}, 3.70 \mathrm{~Hz}, 3 \mathrm{H}, \mathrm{Me})$, $3.72(\mathrm{dd}, 7.65 \mathrm{~Hz}, 1.17 \mathrm{~Hz}, 3 \mathrm{H}, \mathrm{Me}), 4.11\left(\mathrm{~s}, 5 \mathrm{H}, \mathrm{C}_{5} \mathrm{H}_{5}\right)$, $4.22\left(\mathrm{~s}, 5 \mathrm{H}, \mathrm{C}_{5} \mathrm{H}_{5}\right), 4.394 .27\left(\mathrm{~m}, 6 \mathrm{H}, \mathrm{C}_{5} \mathrm{H}_{4}\right), 4.74(\mathrm{~m}$, $\left.1 \mathrm{H}, \mathrm{C}_{5} \mathrm{H}_{4}\right), 4.82\left(\mathrm{~m}, 1 \mathrm{H}, \mathrm{C}_{5} \mathrm{H}_{4}\right), 6.98(\mathrm{~m}, 1 \mathrm{H},=\mathrm{CH}) .{ }^{13} \mathrm{C}$ NMR $\left(62 \mathrm{MHz}, \mathrm{CDCl}_{3}\right): \delta 44.1,51.9(\mathrm{Me}), 68.9,69.3$ $\left(\mathrm{C}_{5} \mathrm{H}_{5}\right), 68.0,68.1,68.2,68.4,68.7,68.8,69.0,69.7,83.7$, $87.6\left(\mathrm{C}_{5} \mathrm{H}_{4}\right), 125.2\left(\mathrm{C}_{\gamma}\right), 135.1\left(\mathrm{C}_{\beta}\right), 206.3\left(\mathrm{CO}_{c i s}\right), 213.4$ $\left(\mathrm{CO}_{\text {trans }}\right), 261.9\left(\mathrm{C}_{\alpha}\right)$. MAS (FAB), $m / z$ (rel. $\left.{ }^{98} \mathrm{Mo}\right): 689$ $\left[\begin{array}{lllll} & \left.\mathrm{M}^{+}\right], & 605 & {\left[(\mathrm{M}-3 \mathrm{CO})^{+}\right.}\end{array}\right], \quad 549 \quad\left[(\mathrm{M}-5 \mathrm{CO})^{+}\right], \quad 504$ $\left[\left(\mathrm{M}-5 \mathrm{CO}-\mathrm{HNMe}_{2}\right)^{+}\right] . \mathrm{C}_{30} \mathrm{H}_{25} \mathrm{MoFe}_{2} \mathrm{NO}_{5}$ (687.2).

\subsection{Pentacarbonyl [3,3-diferrocenyl-1-( $N, N$ - dimethylamino) prop-2-enylidene]tungsten (10c)}

The reaction of $0.44 \mathrm{~g}(0.6 \mathrm{mmol})$ of $1 \mathrm{c}$ with $\mathrm{HNMe}_{2}$ was carried out analogously to that of 1a. After addition of the amine the solution was stirred for approx. $4 \mathrm{~h}$ at $-10{ }^{\circ} \mathrm{C}$ to $-5^{\circ} \mathrm{C}$. For the purification of $10 \mathrm{c}$ see 10a. Yield: $0.37 \mathrm{~g}(0.48 \mathrm{mmol}, 80 \%)$. IR (pentane, $\left.\mathrm{cm}^{-1}\right): v(\mathrm{CO})$ 2060 w, 1965 w, 1932 s, sh, 1925 vs. ${ }^{1}$ H NMR $(250 \mathrm{MHz}$, $\left.\mathrm{CDCl}_{3}\right): \delta 3.05(\mathrm{~s}, 3 \mathrm{H}, \mathrm{Me}), 3.70(\mathrm{~s}, 3 \mathrm{H}, \mathrm{Me}), 4.11(\mathrm{~s}, 5 \mathrm{H}$, $\left.\mathrm{C}_{5} \mathrm{H}_{5}\right), 4.21\left(\mathrm{~s}, 5 \mathrm{H}, \mathrm{C}_{5} \mathrm{H}_{5}\right), 4.364 .25\left(\mathrm{~m}, 6 \mathrm{H}, \mathrm{C}_{5} \mathrm{H}_{4}\right), 4.73$ $\left(\mathrm{m}, 1 \mathrm{H}, \mathrm{C}_{5} \mathrm{H}_{4}\right), 4.82\left(\mathrm{~m}, 1 \mathrm{H}, \mathrm{C}_{5} \mathrm{H}_{4}\right), 6.95(\mathrm{~m}, 1 \mathrm{H},=\mathrm{CH})$. ${ }^{13} \mathrm{C}$ NMR $\left(62 \mathrm{MHz}, \mathrm{CDCl}_{3}\right): \delta$ 43.9, $52.1(\mathrm{Me}), 68.0$, 68.2, 68.4, 68.8, 69.5, 83.2, 87.1 $\left(\mathrm{C}_{5} \mathrm{H}_{4}\right), 68.9,69.3$ $\left(\mathrm{C}_{5} \mathrm{H}_{5}\right), 126.8\left(\mathrm{C}_{\gamma}\right), 135.9\left(\mathrm{C}_{\beta}\right), 198.2\left(J_{\mathrm{WC}} 126.5 \mathrm{~Hz}\right.$, $\left.\mathrm{CO}_{\text {cis }}\right), 203.1\left(J_{\mathrm{WC}} 124.0 \mathrm{~Hz}, \mathrm{CO}_{\text {trans }}\right), 250.0\left(\mathrm{C}_{\alpha}\right) . \mathrm{MS}$ $(\mathrm{EI}, \quad 70 \mathrm{eV}) \quad m / z: \quad 775 \quad\left[\mathrm{M}^{+}\right], \quad 691 \quad\left[(\mathrm{M}-3 \mathrm{CO})^{+}\right], \quad 663$ $\left[(\mathrm{M}-4 \mathrm{CO})^{+}\right], 635\left[(\mathrm{M}-5 \mathrm{CO})^{+}\right] \cdot \mathrm{C}_{30} \mathrm{H}_{25} \mathrm{WFe}_{2} \mathrm{NO}_{5}(775.1)$.

\subsection{Pentacarbonyl[5,5-diferrocenyl-3-diethylamino-4- methyl-pentatrien-1,2,4-ylidene ]chromium (11a)}

At $-45^{\circ} \mathrm{C}, 1 \mathrm{ml}$ of $N, N$-dimethylamino-1-propyne was added to a solution of $0.35 \mathrm{~g}(0.6 \mathrm{mmol})$ of $1 \mathrm{a}$ in $20 \mathrm{ml}$ of $\mathrm{CH}_{2} \mathrm{Cl}_{2}$. The solution was stirred for a total of $15 \mathrm{~min}$ at $-20{ }^{\circ} \mathrm{C}$. After $1 \mathrm{~min}$ the deep blue solution started to turn violet. After $15 \mathrm{~min}$ the reaction was complete and the colour of the solution was red. The solvent was removed in vacuo and the residue was chromatographed at $-35^{\circ} \mathrm{C}$ on basic alumina. With pentane $/ \mathrm{CH}_{2} \mathrm{Cl}_{2}$ (6:1) red 11a was eluted. Yield: $0.34 \mathrm{~g}(0.48 \mathrm{mmol}, 80 \%)$. IR (pentane, 
$\left.\mathrm{cm}^{-1}\right): v(\mathrm{CO}) 1940$ vs, $1931 \mathrm{~s} ; v(\mathrm{CCC}) 1978 \mathrm{w} .{ }^{1} \mathrm{H}$ NMR $\left(250 \mathrm{MHz}, \mathrm{CDCl}_{3}\right): \delta 0.97(\mathrm{t}, \quad 7.26 \mathrm{~Hz}, 3 \mathrm{H}$, $\left.\mathrm{CH}_{2} \mathrm{CH}_{3}\right), 1.28\left(\mathrm{t}, 7.20 \mathrm{~Hz}, 3 \mathrm{H}, \mathrm{CH}_{2} \mathrm{CH}_{3}\right), 2.48(\mathrm{~s}, 3 \mathrm{H}$, $\mathrm{Me}), 2.98\left(\mathrm{~m}, 1 \mathrm{H}, \mathrm{CH}_{2} \mathrm{CH}_{3}\right), 3.42\left(\mathrm{~m}, 2 \mathrm{H}, \mathrm{CH}_{2} \mathrm{CH}_{3}\right)$, $3.54\left(\mathrm{~m}, 1 \mathrm{H}, \mathrm{CH}_{2} \mathrm{CH}_{3}\right), 4.104 .30\left(\mathrm{~m}, 2 \mathrm{H}, \mathrm{C}_{5} \mathrm{H}_{4}\right), 4.15(\mathrm{~s}$, $\left.5 \mathrm{H}, \mathrm{C}_{5} \mathrm{H}_{5}\right), 4.24\left(\mathrm{~s}, 5 \mathrm{H}, \mathrm{C}_{5} \mathrm{H}_{5}\right), 4.43\left(\mathrm{~m}, 3 \mathrm{H}, \mathrm{C}_{5} \mathrm{H}_{4}\right), 4.81$ $\left(\mathrm{m}, 2 \mathrm{H}, \mathrm{C}_{5} \mathrm{H}_{4}\right), 5.08\left(\mathrm{~m}, 1 \mathrm{H}, \mathrm{C}_{5} \mathrm{H}_{4}\right) .{ }^{13} \mathrm{C}$ NMR $(62 \mathrm{MHz}$, $\left.\mathrm{CDCl}_{3}\right): \delta 11.4,12.8\left(\mathrm{CH}_{2} \mathrm{CH}_{3}\right), 22.5(\mathrm{Me}), 45.3,48.1$ $\left(\mathrm{CH}_{2} \mathrm{CH}_{3}\right), 67.9,68.2,68.35,68.6,69.1,69.7,70.7,71.6$, 83.6, $88.9\left(\mathrm{C}_{5} \mathrm{H}_{4}\right), 69.4,70.0\left(\mathrm{C}_{5} \mathrm{H}_{5}\right), 119.4\left(\mathrm{C}_{\delta}\right), 127.0$ $\left(\mathrm{C}_{\beta}\right), 136.7\left(\mathrm{C}_{\varepsilon}\right), 158.7\left(\mathrm{C}_{\gamma}\right), 218.0\left(\mathrm{CO}_{c i s}\right), 218.7\left(\mathrm{C}_{\alpha}\right)$, 223.9 ( $\left.\mathrm{CO}_{\text {trans }}\right)$. MS (EI, $\left.70 \mathrm{eV}\right) \mathrm{m} / z: 709\left[\mathrm{M}^{+}\right], 597$ $\left[(\mathrm{M}-4 \mathrm{CO})^{+}\right], 569\left[(\mathrm{M}-5 \mathrm{CO})^{+}\right], 539\left[\left(\mathrm{M}-5 \mathrm{CO}-\mathrm{C}_{2} \mathrm{H}_{6}\right)^{+}\right]$. $\mathrm{C}_{35} \mathrm{H}_{31} \mathrm{CrFe}_{2} \mathrm{NO}_{5}$ (709.3).

\subsection{Pentacarbonyl [5,5-diferrocenyl-3-diethylamino-4- methyl-pentatrien-1,2,4-ylidene Jmolybdenum (11b)}

The synthesis of $11 \mathbf{b}$ from $0.39 \mathrm{~g}(0.6 \mathrm{mmol})$ of $1 \mathbf{c}$ and $1 \mathrm{ml}$ of $N, N$-dimethylamino-1-propyne and the purification of 11b was carried out analogously to 11a. Exception: After addition of the alkyne the solution was stirred for $4 \mathrm{~h}$ at $10{ }^{\circ} \mathrm{C}$. Yield: $0.18 \mathrm{~g}(0.24 \mathrm{mmol}, 60 \%)$. IR (pentane, $\left.\mathrm{cm}^{-1}\right): v(\mathrm{CO}) \quad 1941$ vs, $1930 \mathrm{~s} ; v(\mathrm{CCC}) 1978$ w. ${ }^{1} \mathrm{H}$ NMR $\left(250 \mathrm{MHz}, \mathrm{CDCl}_{3}\right): \delta 0.97(\mathrm{t}, \quad 7.26 \mathrm{~Hz}, 3 \mathrm{H}$, $\left.\mathrm{CH}_{2} \mathrm{CH}_{3}\right), 1.27\left(\mathrm{t}, 7.19 \mathrm{~Hz}, 3 \mathrm{H}, \mathrm{CH}_{2} \mathrm{CH}_{3}\right), 2.47(\mathrm{~s}, 3 \mathrm{H}$, $\mathrm{Me}), 2.95\left(\mathrm{~m}, 1 \mathrm{H}, \mathrm{CH}_{2} \mathrm{CH}_{3}\right), 3.43\left(\mathrm{~m}, 2 \mathrm{H}, \mathrm{CH}_{2} \mathrm{CH}_{3}\right)$, $3.51\left(\mathrm{~m}, 1 \mathrm{H}, \mathrm{CH}_{2} \mathrm{CH}_{3}\right), 4.17\left(\mathrm{~s}, 5 \mathrm{H}, \mathrm{C}_{5} \mathrm{H}_{5}\right), 4.22(\mathrm{~s}, 5 \mathrm{H}$,
$\left.\mathrm{C}_{5} \mathrm{H}_{5}\right), 4.304 .15\left(\mathrm{~m}, 2 \mathrm{H}, \mathrm{C}_{5} \mathrm{H}_{4}\right), 4.43\left(\mathrm{~m}, 3 \mathrm{H}, \mathrm{C}_{5} \mathrm{H}_{4}\right)$, $4.78\left(\mathrm{~m}, 2 \mathrm{H}, \mathrm{C}_{5} \mathrm{H}_{4}\right), 5.05\left(\mathrm{~m}, 1 \mathrm{H}, \mathrm{C}_{5} \mathrm{H}_{4}\right) .{ }^{13} \mathrm{C} \mathrm{NMR}$ $\left(62 \mathrm{MHz}, \mathrm{CDCl}_{3}\right): \delta$ 11.4, $12.7\left(\mathrm{CH}_{2} \mathrm{CH}_{3}\right), 22.6(\mathrm{Me})$, 48.3, $45.4\left(\mathrm{CH}_{2} \mathrm{CH}_{3}\right), 69.4,70.1\left(\mathrm{C}_{5} \mathrm{H}_{5}\right), 68.0,68.2,68.7$, 68.8, 68.9, 69.8, 70.7, 71.5, 83.7, $86.0\left(\mathrm{C}_{5} \mathrm{H}_{4}\right), 118.0\left(\mathrm{C}_{\delta}\right)$, $127.0\left(\mathrm{C}_{\beta}\right), 137.1\left(\mathrm{C}_{\varepsilon}\right), 159.7\left(\mathrm{C}_{\gamma}\right), 206.0\left(\mathrm{CO}_{c i s}\right), 211.6$ $\left(\mathrm{C}_{\alpha}\right), 213.0\left(\mathrm{CO}_{\text {trans }}\right)$. MS (FAB) $, \mathrm{m} / \mathrm{z}\left(\mathrm{rel} .{ }^{98} \mathrm{Mo}\right): 755$ $\left[\begin{array}{llllll}\left.\mathrm{M}^{+}\right], & 671 & {\left[(\mathrm{M}-3 \mathrm{CO})^{+}\right],} & 615 & {\left[(\mathrm{M}-5 \mathrm{CO})^{+}\right],} & 542\end{array}\right.$ $\left[\left(\mathrm{M}-5 \mathrm{CO}-\mathrm{HNEt}_{2}\right)^{+}\right] . \mathrm{C}_{35} \mathrm{H}_{31} \mathrm{MoFe}_{2} \mathrm{NO}_{5}$ (753.3).

\subsection{Pentacarbonyl [5,5-diferrocenyl-3-diethylamino-4- methyl-pentatrien-1,2,4-ylidene]tungsten (11c)}

The synthesis of $11 \mathrm{c}$ from $0.44 \mathrm{~g}(0.6 \mathrm{mmol})$ of $1 \mathrm{c}$ and $1 \mathrm{ml}$ of $N, N$-dimethylamino-1-propyne and the purification of 11c was carried out analogously to $11 \mathrm{~b}$. Yield: $0.33 \mathrm{~g}$ $(0.39 \mathrm{mmol}, 65 \%)$ of 11c. IR (pentane, $\left.\mathrm{cm}^{-1}\right)$ : $v(\mathrm{CO})$ 1935 vs, $1925 \mathrm{~s} ; v(\mathrm{CCC}) 1978 \mathrm{w} .{ }^{1} \mathrm{H}$ NMR $(250 \mathrm{MHz}$, $\left.\mathrm{CDCl}_{3}\right): \delta 0.98\left(\mathrm{t}, 7.25 \mathrm{~Hz}, 3 \mathrm{H}, \mathrm{CH}_{2} \mathrm{CH}_{3}\right), 1.27(\mathrm{t}$, $\left.7.19 \mathrm{~Hz}, 3 \mathrm{H}, \mathrm{CH}_{2} \mathrm{CH}_{3}\right), 2.46(\mathrm{~s}, 3 \mathrm{H}, \mathrm{Me}), 2.94(\mathrm{~m}, 1 \mathrm{H}$, $\left.\mathrm{CH}_{2} \mathrm{CH}_{3}\right), 3.42\left(\mathrm{~m}, 2 \mathrm{H}, \mathrm{CH}_{2} \mathrm{CH}_{3}\right), 3.51\left(\mathrm{~m}, 1 \mathrm{H}, \mathrm{CH}_{2} \mathrm{CH}_{3}\right)$, $4.17\left(\mathrm{~s}, 5 \mathrm{H}, \mathrm{C}_{5} \mathrm{H}_{5}\right), 4.22\left(\mathrm{~s}, 5 \mathrm{H}, \mathrm{C}_{5} \mathrm{H}_{5}\right), 4.104 .30(\mathrm{~m}, 2 \mathrm{H}$, $\left.\mathrm{C}_{5} \mathrm{H}_{4}\right), 4.43\left(\mathrm{~m}, 3 \mathrm{H}, \mathrm{C}_{5} \mathrm{H}_{4}\right), 4.80\left(\mathrm{~m}, 2 \mathrm{H}, \mathrm{C}_{5} \mathrm{H}_{4}\right), 5.05(\mathrm{~m}$, $\left.1 \mathrm{H}, \mathrm{C}_{5} \mathrm{H}_{4}\right) \cdot{ }^{13} \mathrm{C}$ NMR $\left(62 \mathrm{MHz}, \mathrm{CDCl}_{3}\right): \delta 11.4,12.7$ $\left(\mathrm{CH}_{2} \mathrm{CH}_{3}\right), 22.5(\mathrm{Me}), 45.5,48.3\left(\mathrm{CH}_{2} \mathrm{CH}_{3}\right), 69.4,70.0$ $\left(\mathrm{C}_{5} \mathrm{H}_{5}\right), 68.0,68.2,68.7,68.8,68.9,69.2,70.7,71.5,83.6$, $85.9\left(\mathrm{C}_{5} \mathrm{H}_{4}\right), 117.5\left(\mathrm{C}_{\delta}\right), 126.9\left(\mathrm{C}_{\beta}\right), 136.3\left(\mathrm{C}_{\varepsilon}\right), 160.3\left(\mathrm{C}_{\gamma}\right)$, $196.2\left(\mathrm{C}_{\alpha}\right), 197.3\left(J_{\mathrm{WC}} 125 \mathrm{~Hz}, \mathrm{CO}_{c i s}\right), 203.7\left(J_{\mathrm{WC}}\right.$

Table 3

Crystallographic data and refinement methods for $\mathbf{5 a}, \mathbf{7 a}$, and $\mathbf{9 a}$

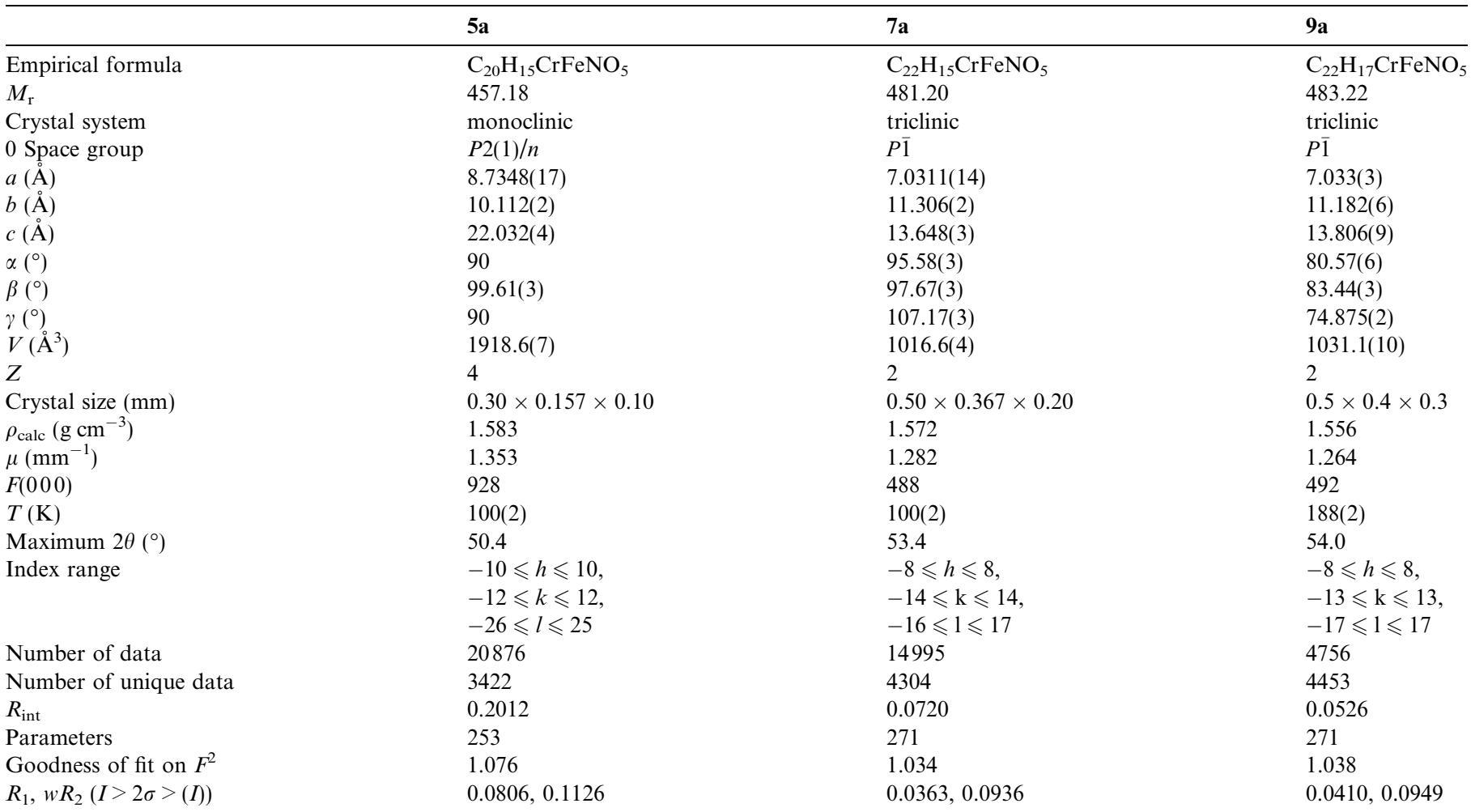


$\left.123.9 \mathrm{~Hz}, \mathrm{CO}_{\text {trans }}\right) . \mathrm{MS}(\mathrm{EI}, 70 \mathrm{eV}), \mathrm{m} / z: 841\left[\mathrm{M}^{+}\right], 757$ $\left[(\mathrm{M}-3 \mathrm{CO})^{+}\right], 701\left[(\mathrm{M}-5 \mathrm{CO})^{+}\right], 628\left[\left(\mathrm{M}-5 \mathrm{CO}-\mathrm{HNEt}_{2}\right)^{+}\right]$. $\mathrm{C}_{35} \mathrm{H}_{31} \mathrm{WFe}_{2} \mathrm{NO}_{5}$ (841.2).

\subsection{X-ray structure analysis of 5a, 7a, and $9 \boldsymbol{a}$}

Single crystals of $\mathbf{5 a}, 7 \mathbf{a}$, and $9 \mathbf{a}$ suitable for X-ray structure analysis were obtained by slow diffusion of petrol ether into solutions of 5a, 7a, and 9a in $\mathrm{CH}_{2} \mathrm{Cl}_{2}$ at $4{ }^{\circ} \mathrm{C}$. The measurements were performed with a crystal mounted on a glass fibre on a Stoe IPDS II diffractometer (graphite monochromator, Mo $\mathrm{K} \alpha$, radiation, $\lambda \quad 0.71073 \AA$, scan rate $330^{\circ} \mathrm{min}^{-1}$ in $\omega$ ). The structures were solved by direct methods using the SHELX-97 program package [23]. The position of the hydrogen atoms were calculated by assuming ideal geometry and their coordinates were refined together with those of the attached carbon atoms as riding-model. All other atoms were refined anisotropically. For the crystallographic data and the refinement details see Table 3.

\section{Acknowledgement}

Support of these investigations by the Wacker-Chemie $\mathrm{GmbH}$ (gift of chemicals) is gratefully acknowledged.

\section{Appendix A. Supplementary material}

CCDC 667920, 667921 and 667922 contain the supplementary crystallographic data for $\mathbf{5 a}, 7 \mathbf{a}$ and $9 \mathbf{a}$. These data can be obtained free of charge from The Cambridge Crystallographic Data Centre via www.ccdc.cam.ac.uk/data request/cif. Supplementary data associated with this article can be found, in the online version, at doi:10.1016/j.ica. 2008.02.024.

\section{References}

[1] For reviews on the chemistry of allenylidene complexes see e.g.: (a) C. Bruneau, P.H. Dixneuf, Angew. Chem. 118 (2006) 2232;

C. Bruneau, P.H. Dixneuf, Angew. Chem., Int. Ed. 45 (2006) 2176;

(b) H. Fischer, N. Szesni, Coord. Chem. Rev. 248 (2004) 1659;

(c) S. Rigaut, D. Touchard, P.H. Dixneuf, Coord. Chem. Rev. 248 (2004) 1585;

(d) R.F. Winter, S. Zális, Coord. Chem. Rev. 248 (2004) 1565; (e) V. Cadierno, M. Pilar Gamasa, J. Gimeno, Eur. J. Inorg. Chem. (2001) 571 ;

(f) M.I. Bruce, Chem. Rev. 98 (1998) 2797.

[2] N. Szesni, M. Drexler, J. Maurer, R.F. Winter, F. de Montigny, C. Lapinte, S. Steffens, J. Heck, B. Weibert, H. Fischer, Organometallics 25 (2006) 5774.

[3] These methods were originally introduced by (a) E.O. Fischer, H. J. Kalder, A. Frank, F.H. Kohler, G. Huttner, Angew. Chem. 88 (1976) 683 ;

(b) E.O. Fischer, H. J. Kalder, A. Frank, F.H. Kohler, G. Huttner, Angew. Chem., Int. Ed. Engl. 15 (1976) 623;

(c) J.P. Selegue, Organometallics 1 (1982) 217.

[4] See e.g.: (a) H. Berke, Chem. Ber. 113 (1980) 1370;

(b) H. Fischer, D. Reindl, G. Roth, Z. Naturforsch. 49b (1994) 1207.

[5] See e.g.: G. Roth, H. Fischer, Organometallics 15 (1996) 1139.

[6] See e.g.: H. Fischer, N. Szesni, G. Roth, N. Burzlaff, B. Weibert, J. Organomet. Chem. 683 (2003) 301.

[7] E.g. (a) N. Szesni, B. Weibert, H. Fischer, Inorg. Chim. Acta 358 (2005) 1645;

(b) M. Drexler, T. Haas, S. M. Yu, H.S. g. Beckmann, B. Weibert, H. Fischer, J. Organomet. Chem. 690 (2005) 3700.

[8] M.A. Sierra, M.J. Mancheno, J.C. del Amo, I. Fernandez, M. Gomez Gallego, M. Rosario Torres, Organometallics 22 (2003) 384.

[9] T. Haas, Diploma Thesis, Universitat Konstanz, 2004.

[10] For early reports see: (a) C.G. Kreiter, Angew. Chem. 80 (1968) 402; (b) C.G. Kreiter, Angew. Chem., Int. Ed. Engl. 7 (1968) 390;

(c) C.P. Casey, R.A. Boggs, R.L. Anderson, J. Am. Chem. Soc. 94 (1972) 8947.

[11] H. Fischer, G. Roth, D. Reindl, C. Troll, J. Organomet. Chem. 454 (1993) 133.

[12] F. Stein, M. Duetsch, E. Pohl, R. Herbst lrmer, A. de Meijere, Organometallics 12 (1993) 2556.

[13] N. Szesni, B. Weibert, H. Fischer, Inorg. Chim. Acta 359 (2006) 617.

[14] G. Roth, D. Reindl, M. Gockel, C. Troll, H. Fischer, Organometallics 17 (1998) 1393.

[15] F.H. Allen, O. Kennard, D.G. Watson, L. Brammer, A.G. Orpen, R. Taylor, J. Chem. Soc., Perkin Trans. 2 (1987) S1.

[16] For a recent review on binuclear complexes linked by an organic unsaturated spacer see: F. Paul, C. Lapinte, Coord. Chem. Rev. 178 180 (1998) 431.

[17] D. Bickar, B. Lukas, G. Neshvad, R.M.G. Roberts, J. Silver, J. Organomet. Chem. 263 (1984) 225.

[18] J. Lukasser, H. Angleitner, H. Schottenberger, H. Kopacka, M. Schweiger, B. Bildstein, K. H. Ongania, K. Wurst, Organometallics 14 (1995) 5566.

[19] W. Kuan Li, E.B. Sokolova, I.E. Chlenov, A.D. Petrov, Dokl. Akad. Nauk SSSR 137 (1961) 280.

[20] M.A. Sierra, M.J. Mancheno, J.C. del Amo, I. Fernández, M. Gómez Gallego, M. Rosario Torres, Organometallics 22 (2003) 384.

[21] M. Dede, Ph.D. Thesis, Universitat Konstanz, 2004.

[22] P.J. Graham, R.V. Lindsey, G.W. Parshall, M.L. Peterson, G.M Whitman, J. Am. Chem. Soc. 79 (1957) 3416.

[23] G.M. Sheldrick, SHELX 97, Programs for Crystal Structure Analysis, Universitat Gottingen, 1997. 